\title{
Thecamoebian communities as proxies of seasonality in Lake Sadatal in the Ganga-Yamuna Plains of North India
}

\author{
Anjum Farooqui, Arun Kumar, and Graeme T. Swindles
}

\begin{abstract}
Thecamoebians are testate protists that occur in a variety of freshwater habitats and brackish environments. They have been successfully used as proxies for a variety of environmental and climatic parameters in limnological and paleolimnological studies. The perennial Lake Sadatal is situated near the small town of Mallanwan (Latitude $27^{\circ}$ 3' 0" North and Longitude $80^{\circ}$ 9' 0" East) in the Ganga-Yamuna Plains of North India. Lake Sadatal is a shallow remnant of a past oxbow lake left by the meandering Ganga River and its tributaries (maximum depth $\sim 1.5 \mathrm{~m}$ during summer and $\sim 3.0 \mathrm{~m}$ during July-August monsoon season). The soil around this region is saline, sodium rich, and the maximum soil alkalinity is $\mathrm{pH} 10$. This region shows strong seasonality, and average atmospheric temperatures during winter (December-March) range between 7$20^{\circ} \mathrm{C}$ and during summer (April-June) range between $21-45^{\circ} \mathrm{C}(2005-2007)$. Taxonomically diverse and mixed thecamoebians were recovered from Lake Sadatal showing distinct summer and winter communities for three years. Centropyxids and Arcellenids dominate the low humidity, low precipitation cooler months (OctoberMarch) whereas Amphitrema spp. and Difflugia oblonga "triangularis" dominate summer and the high precipitation, high humidity monsoon months (April-September). Dominance of Amphitrema spp. is related to abundance of aquatic weed Lemna detritus at the lake bottom during summer. Total concentrations of thecamoebians were higher during summer monsoon months than winter.
\end{abstract}

Anjum Farooqui. Birbal Sahni Institute of Palaeobotany, 53 University Road, Lucknow 226 007, India afarooqui_2000@yahoo.com

Arun Kumar. Center for Petroleum and Minerals, Research Institute, King Fahd University of Petroleum and Minerals, Dhahran 31261, Saudi Arabia arunkumarlko@hotmail.com (correspondance author) Present address: Department of Earth Science, Ottawa-Carleton Geoscience Centre, Carleton University, 1125 Colonel By Drive, Ottawa, ON K1S 5B6, Canada Graeme T. Swindles. School of Geography, University of Leeds, Leeds, LS2 9JT, UK G.T.Swindles@leeds.ac.uk 
KEYWORDS: Acid resistant thecamoebians; seasonality; lake sediments; Ganga-Yamuna Plains; India

\section{INTRODUCTION}

Thecamoebians are an artificial polyphyletic group of protozoans also known as agglutinated rhizopods or testate amoebae, and Arcellaceans are a supergroup within thecamoebians (Loeblich and Tappan, 1964). These are unicellular testate (shelled) forms that occur widely in a variety of freshwater habitats (Medioli and Scott, 1983, 1988) and also in marginally brackish environments (Charman et al., 2000; Patterson and Kumar, 2002). They have been widely reported from lake sediments from the tropics to the Arctic region (see references in Patterson and Kumar, 2002; Boudreau et al., 2005), peat bogs (Woodland et al., 1998; Charman et al., 2000; Swindles et al. 2010), and salt marshes (Charman et al., 2002; Roe et al., 2002; Riveiros et al., 2007). Their pre-Quaternary geological record is quite scanty but their oldest forms are reported from the Neoproterozoic (Porter and Knoll, 2000; Porter et al. 2003). Despite a long geological history thecamoebian lineages have shown minimal evolution through time (van Hengstum et al., 2007; Kumar et al., 2011).

Published thecamoebian studies are mainly from the lakes and bogs of higher latitudes in Europe and North America, but they have also been studied from the Arctic region (Beyens et al. 1990; Beyens and Chardez, 1995). There are relatively fewer thecamoebian studies from the tropical regions. Some of them are lakes in Java, Sumatra and Irian Jaya in Indonesia (Hoogenraad and Groot, 1940, 1946; van Oye, 1949; Dalby et al., 2000); lakes in Malaysia (Sudzuki, 1979); brackish water lakes and ponds of nineteenth century Mumbai, India (Carter, 1856, 1864); Bronze Age archaeological site in Porbandar, west coast of India (Farooqui and Gaur, 2007); Lake Cocococha, Peru (Haman and Kohl, 1994), Sokoto River in Nigeria (Green, 1963), wetlands of central Brazil (Green,1975), small lakes and ponds of Barbados, (Roe and Patterson, 2006) and a dam in Colombia (Escobar and Martinez, 2008). Most of these studies except Roe and Patterson (2006) are either descriptive works or simply reports of thecamoebian occurrence. Environmental and paleoenvironmental analysis of the collected data has largely been ignored. Patterson and Kumar (2000a, 2002) provide comprehensive reviews of environmental and paleoecological utility of lacustrine thecamoebians in higher latitudes. Medioli et al. (2003) present a useful bibliography of thecamoebian literature. According to Roe and Patterson (2006), "thecamoebian species can be correlated to a variety of environmental and climatic parameters, including metal and organic pollutant contamination, substrate type, salinity, levels of organics, oxygen concentration, water temperatures, water table fluctuations, humification, changes in intertidal flooding and land use change."

Thecamoebians are proving to be useful proxies for a variety of new environmental and climatic parameters also, for example, water quality indicators in the Greater Toronto area (Roe et al., 2010). Neville et al. (2010a, and in press) show that they can also be used to monitor seasonal environmental changes and ecosystem health in oil sand reclamation wetlands in Northern Alberta. Lakes within different vegetation zones of Alberta also show corresponding biogeographic variations in thecamoebian assemblages (Neville et al. 2010b).

\section{LAKE SADATAL}

The perennial Lake Sadatal is situated near the small town Mallanwan (Latitude $27^{\circ} 3^{\prime} 0^{\prime \prime}$ North and Longitude $80^{\circ} 9^{\prime} 0^{\prime \prime}$ East) in the GangaYamuna plains of north India (Figure 1). There are several lakes and ponds in and around Mallanwan, and most of them are small ephemeral ponds that dry up during summer but Lake Sadatal is a perennial lake located on the eastern edge of the town (Figures 1 and 2). These lakes and ponds are remnants of past oxbow lakes left by the meandering river Ganga in this region. They are usually shallow, and their maximum depth reaches up to $3 \mathrm{~m}$ during the Monsoon season. Photographs of the natural surroundings of Lake Sadatal are shown in Figure 3.

The anthropogenic impact has caused severe environmental stress in Lake Sadatal. Solid biological and chemical waste generated from the town is dumped into this lake. The soil around this region is very saline, sodic, and soil alkalinity can rise up to $\mathrm{pH}$ 10. Pore spaces of the wet soil of this region contain varying amounts of calcium, magnesium, sodium, and potassium ions and the anions of chloride, sulphate, and bicarbonate. Small quantities of various other cations and anions are also present.

This region of India shows strong seasonality. The average atmospheric temperature during winters (December to March) ranges between 7- 20 $\mathrm{C}$ and during summers (April-June) between 21$45^{\circ} \mathrm{C}$. Humidity is high during monsoon months from July to January covering both the south-west 


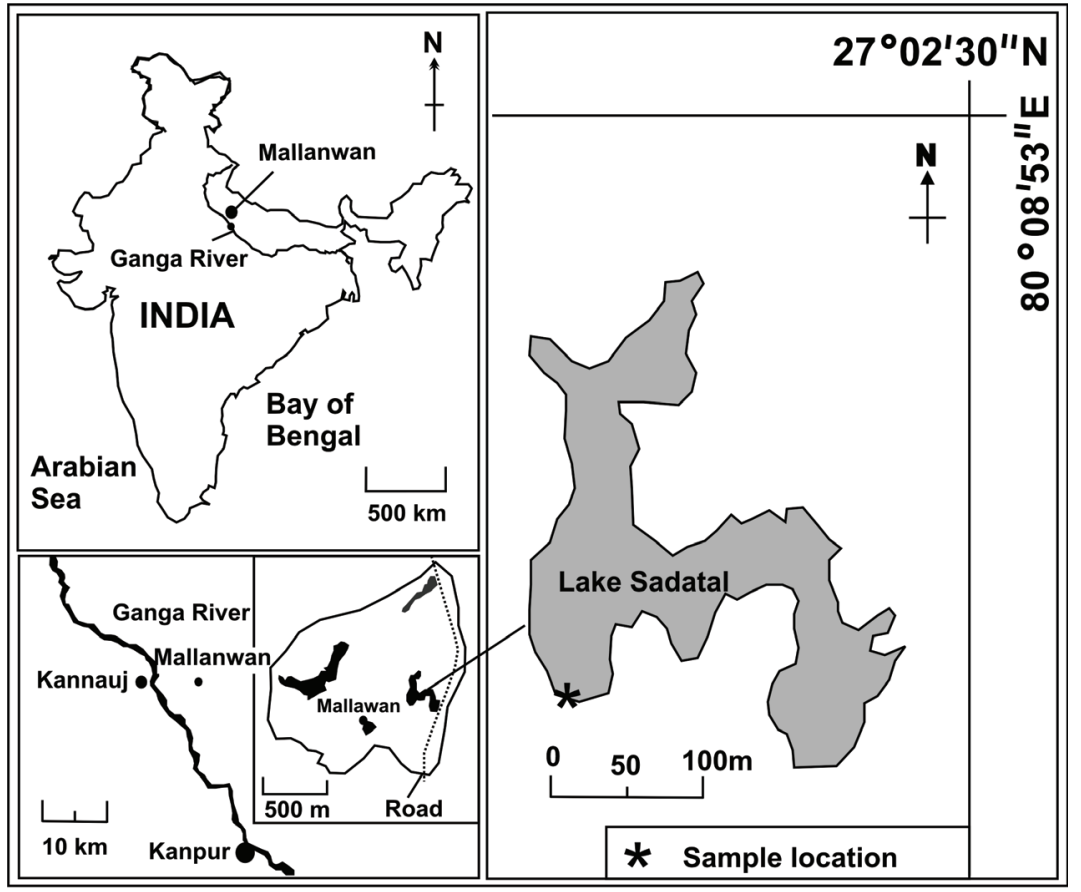

FIGURE 1. Location of Lake Sadatal in India.

summer monsoons and the north-east winter monsoons. Maximum rain fall in July is due to southwest monsoon. The average atmospheric temperature in February is $16^{\circ} \mathrm{C}$ followed by moderate $21^{\circ} \mathrm{C}$ in October and highest $45^{\circ} \mathrm{C}$ in May. The water temperature also varies in a similar pattern but does not exceed $32^{\circ} \mathrm{C}$.

The $\mathrm{pH}$ of the aqueous sediment is alkaline throughout the year, which varies between a high of 9.02 during May to a low of 8.58 in February. The dissolved oxygen (DO) is minimum in May (4.58) and maximum (10.8) in October. Thus, the amount of dissolved oxygen in aqueous soil solution is dependent and inversely proportional to the temperature of water induced by seasonal temperature change. The warmer the water, the less dissolved oxygen was recorded. All the parameters like electrical conductivity (EC), total dissolved solids (TDS), salinity, sodium, potassium, magnesium, iron, copper, and lead show lowest values in October but gradually increase in February and become highest in May (Table 1).

The physico-chemical properties of the water vary with the season that controls growth of Lemna fronds. Its growth begins during the rainy season (July/August) and reaches its peak in October when it almost covers the entire lake surface but in February the Lemna fronds begin to degrade and settle at the lake bottom. By May very few Lemna fronds remain on the lake surface due to increased atmospheric temperature and aridity.

The chemistry of lake water shows seasonally induced chemical changes. The lowest values of nutrients like sodium, potassium, magnesium, and iron and other elements like copper and lead (probably derived from pollution) were recorded in October. This was probably due to absorption of these elements by Lemna from the lake water during its exponential growth phase. There is a slight increase in all these elements along with the salinity, conductivity, and total dissolved solids in February probably due to leaching of these nutrients by Lemna fronds and also due to drainage of nutrients from the surrounding land during the winter monsoon. The highest values of these elements were recorded in May due to addition of Lemna detritus settled at the lake bottom.

\section{MATERIALS AND METHOD}

The sediment-water interface samples were collected from only one location using the Van Veen grab sampler (Eijelkamp, Netherlands; capacity $180 \mathrm{~cm}^{3}$ ) from the periphery of the Lake Sadatal (Figures 1 and 2). This sample location was selected because of its minimal proximity to the nearby human habitation. This study is based on 18 samples of which 12 were collected during 2005 one sample in each month and the remaining 


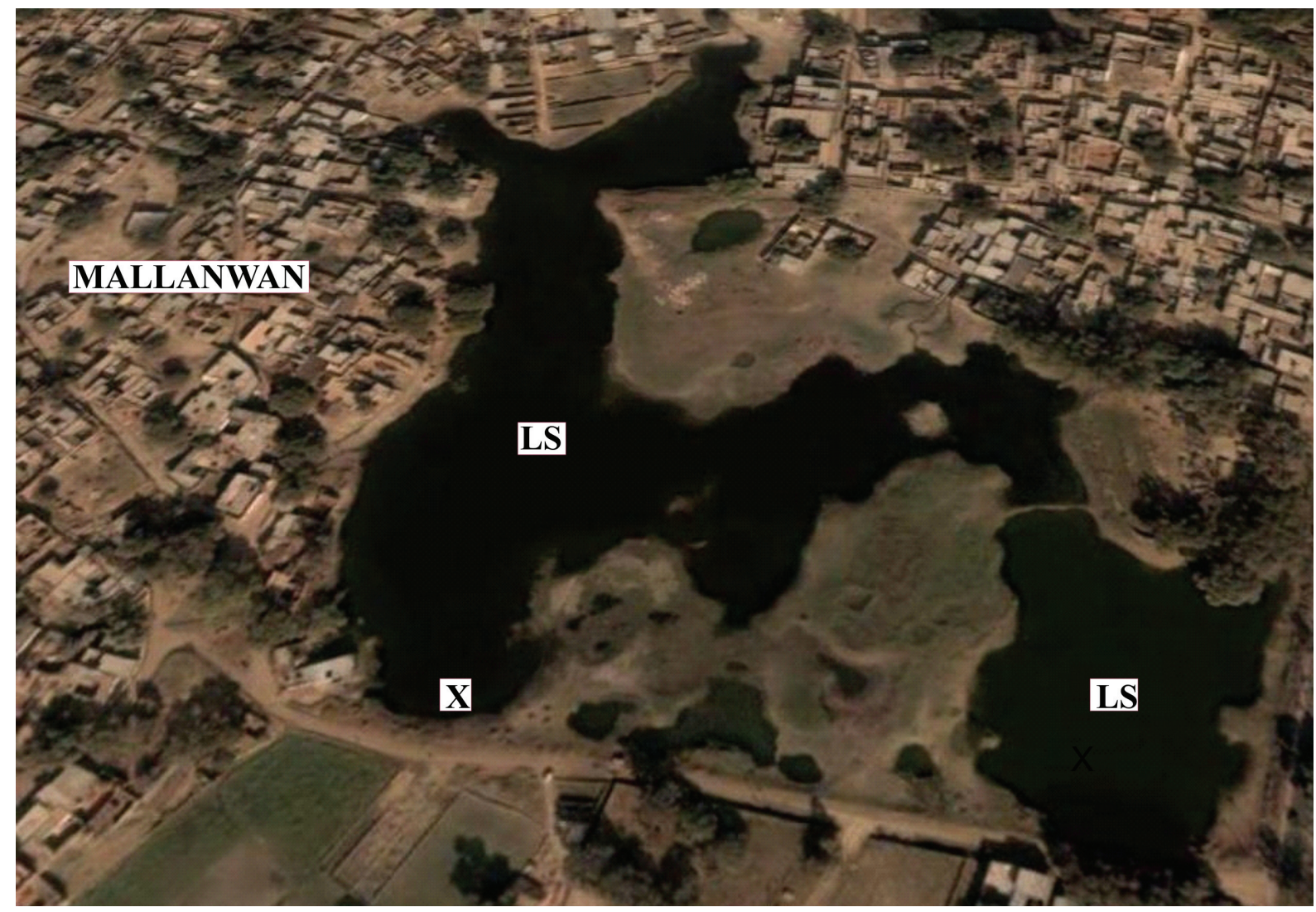

FIGURE 2. Google Map showing location of Lake Sadatal (LS = Lake sadatal; $X=$ sample location).

six were collected in February, May, and December of 2006 and 2007. These months were chosen because of extreme weather conditions, maximum testacean counts, and significant compositional changes observed during preliminary studies carried out every month in the first year (2005) of this study. Thecamoebian counts in each sample are presented in Table 2.

Initial microscopic examination of the samples using standard micropalaeontological method (Patterson and Kumar, 2002) failed to provide any meaningful information because of smaller size, and most specimens remained dark to very dark due to clay and organic particles sticking on the tests. Thus, the palynological preparation method was used to study them on glass slides using reflected light. Five $\mathrm{cm}^{3}$ of sediment sample was boiled in $50 \mathrm{ml}$ of $5 \% \mathrm{KOH}$ mixed with distilled water for 10 minutes. It was sieved through 150 mesh size $(\sim 105 \mu \mathrm{m})$ sieve to remove larger macroscopic material. Each sample was then acetolysed using acetic acid (Erdtman, 1943) and centrifuged at $1000 \mathrm{rpm}$ for 5 minutes. Due to acetolysis opaque thecamoebian specimens became transparent and free from clay, and organic parti- cles thus were easier to study under transmitted light. But due to this process we could not determine the proportion of living thecamoebians (with protoplasm) compared to dead ones. The samples were then sieved through 600 mesh size $(\sim 20 \mu \mathrm{m})$ to remove fine particles that often stick to the tests hindering the clarity and identification. The $>20 \mu \mathrm{m}$ size fraction was collected for this study. Before mounting on slides the residues were stained with Safranin for morphological clarity as suggested by Tolonen (1986) not to observe presence of protoplasm in the specimens.

This method of sample preparation is normally not used by micropaleontologists who study Holocene lacustrine thecamoebians where a much simpler method using water is preferred so that delicate fossils or sub-fossils are not damaged or totally destroyed (Patterson and Kumar 2000a, b, 2002). However, acid- resistant thecamoebians have been reported from the palynological slides of Holocene sediments from the fjords of Vancouver Island, Canada (Kumar and Patterson, 2002), Cretaceous sediments of Saudi Arabia (Kumar, 2011), and Permian sediments of Himalayas in India (Kumar et al. 2011). It is true that there must be 


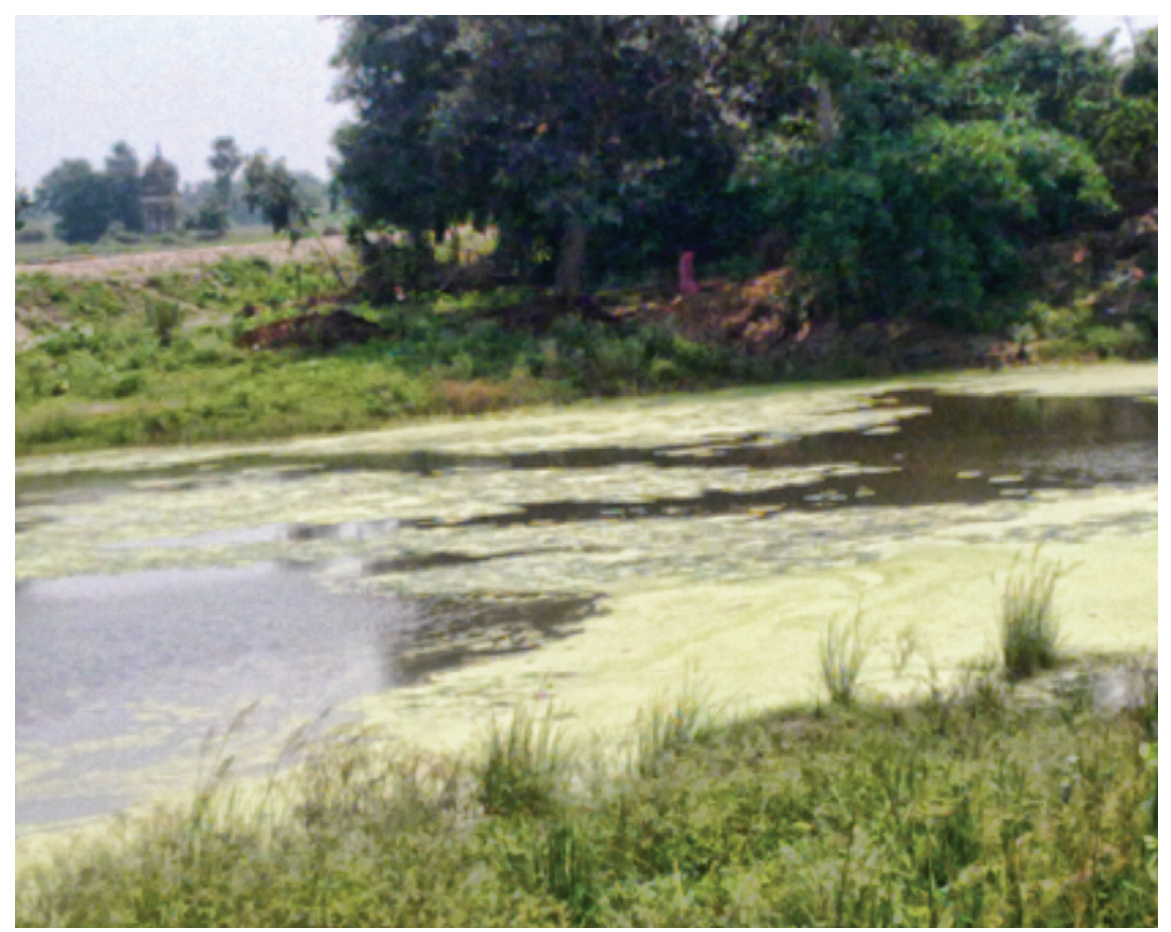

FIGURE 3. Photograph showing the lake and its surroundings.

some information loss using palynological preparations for thecamoebian studies because only autogenous proteinaceous tests are acid resistant, and most other types will not survive harsh chemical and mechanical (centrifuging at high rpm) treatment. However, rich and diverse forms of thecamoebians were recovered from all sedimentwater interface samples from Lake Sadatal using this method. This method also shows a new way to study thecamoebians from pre-Quaternary soft and hard sediments. Two slides of each sample were prepared and all the specimens were counted. Percentage abundances of each taxa are presented in Figures 4 and 5 . The nomenclature and identification of thecamoebians is after Tolonen (1986) and Kumar and Dalby (1998).

The physical and chemical data about sediment samples were measured in the field and in laboratory. For this purpose $10 \mathrm{~g}$ of dried sample (at $50^{\circ} \mathrm{C}$ ) was dissolved in $100 \mathrm{ml}$ of de-ionized water and kept overnight after rigorous shaking for one hour. Parameters like $\mathrm{pH}$, dissolved oxygen (DO),

TABLE 1. Abiotic characteristics of surface sediments (sediment-water interface) in Lake Sadatal during 2005.

\begin{tabular}{|c|c|c|c|c|c|c|c|c|c|c|c|c|}
\hline PARAMETERS & Jan & Feb & March & April & May & June & July & Aug & Sept & Oct & Nov & Dec \\
\hline $\mathrm{pH}$ & 7.2 & 7.0 & 7.0 & 7.0 & 8.4 & 8.0 & 8.0 & 8.0 & 7.6 & 7.0 & 7.0 & 7.0 \\
\hline Salinity $\mathrm{ppt}$ & 0.9 & 1.4 & 1.5 & 1.5 & 1.8 & 1.9 & 1.8 & 1.6 & 0.9 & 0.7 & 1.0 & 0.6 \\
\hline $\mathrm{EC}, \mathrm{mS} / \mathrm{cm}$ & .432 & .628 & .701 & .714 & 1.67 & 1.84 & 1.70 & .843 & .532 & .242 & .689 & .172 \\
\hline TDS, mg/L & 643 & 889 & 899 & 1011 & 1236 & 1432 & 1289 & 954 & 789 & 345 & 634 & 532 \\
\hline $\begin{array}{l}\text { AverageAtmospheric } \\
\text { Temperature, }{ }^{\circ} \mathrm{C}\end{array}$ & 15.5 & 21.8 & 24 & 30 & 31.3 & 31.1 & 29.4 & 29.4 & 29.4 & 26.6 & 20.9 & 16.6 \\
\hline Temp. Minimum & 7.6 & 13.6 & 15.9 & 20.5 & 24.9 & 25.6 & 25.3 & 25.2 & 24.5 & 20 & 13.7 & 9.8 \\
\hline Temp. Maximum & 25.8 & 31.4 & 33.5 & 39.3 & 38.7 & 38.1 & 34.6 & 34.7 & 35.2 & 34.4 & 29.5 & 25.4 \\
\hline $\begin{array}{l}\text { Dissolved oxygen in Water (mg/ } \\
\text { L) }\end{array}$ & 8.6 & 7.8 & 7.0 & 6.5 & 4.6 & 3.2 & 4.0 & 5.7 & 4.9 & 6.2 & 9.5 & 9.0 \\
\hline Sodium, $(\mathrm{mg} / \mathrm{g})$ & 89.2 & 107.8 & 112 & 134 & 174 & 157.3 & 184.5 & 197.2 & 178.2 & 98 & 84 & 97.4 \\
\hline Potassium, $(\mathrm{mg} / \mathrm{g})$ & 67 & 80.84 & 72 & 98 & 112 & 89 & 102 & 123 & 97.3 & 45.9 & 57.3 & 47.8 \\
\hline Magnesium (mg/g) & 32.1 & 24.3 & 43 & 44 & 48 & $\begin{array}{ll}49.7 \\
\end{array}$ & 46 & 32 & 22 & 25 & 11 & 23.8 \\
\hline Iron (mg/g) & .46 & .59 & .51 & .84 & .89 & .93 & .87 & .65 & .57 & .32 & .43 & .37 \\
\hline Copper $(\mathrm{mg} / \mathrm{g})$ & .34 & .22 & .29 & .42 & .67 & .94 & .86 & .91 & .75 & .67 & .42 & .21 \\
\hline Lead $(\mathrm{mg} / \mathrm{g})$ & .10 & .13 .4 & .21 & .23 & .26 & .32 & .28 & .10 & .9 & .9 & .12 & .8 \\
\hline
\end{tabular}


TABLE 2a. Numerical distribution of thecamoebians in 18 samples from Lake Sadatal (numbers within parenthesis are percentage values).

\begin{tabular}{|c|c|c|c|c|c|c|c|c|c|c|c|c|c|c|c|}
\hline 2005 & $\begin{array}{l}\text { Total } \\
\text { Count }\end{array}$ & 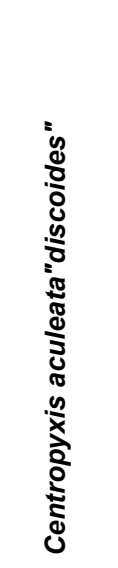 & 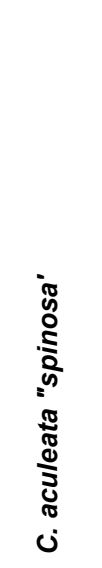 & 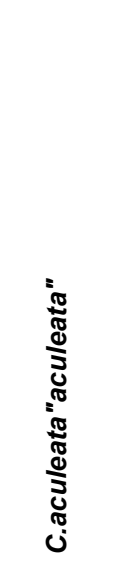 & 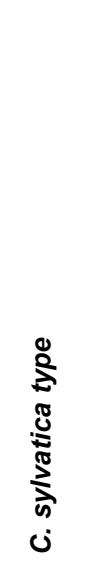 & 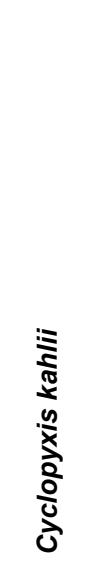 & 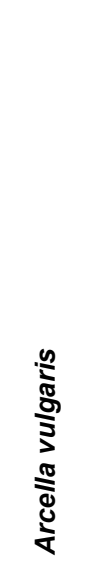 & 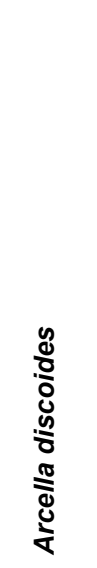 & 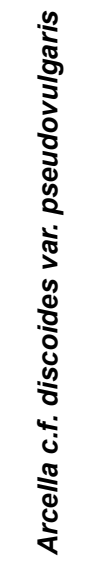 & 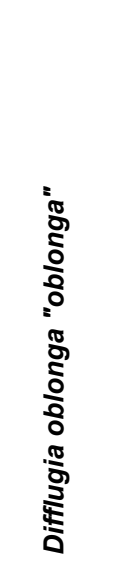 & 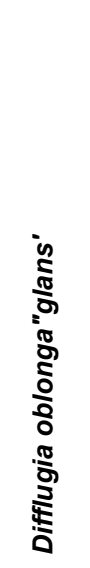 & 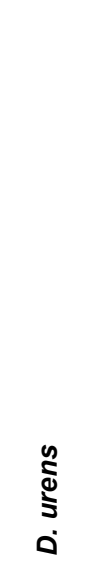 & 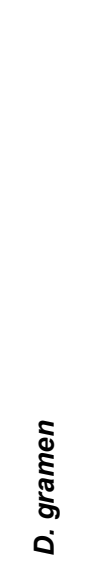 & $\begin{array}{l}\stackrel{x}{\Xi} \\
\stackrel{0}{\vdots}\end{array}$ & 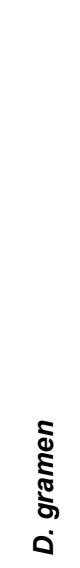 \\
\hline Jan & 65 & $7(10.8)$ & $8(12.3)$ & $18(27.7)$ & $1(1.5)$ & $2(3.1)$ & $2(3.1)$ & $2(3.1)$ & $1(1.5)$ & $6(9.2)$ & $2(3.1)$ & $1(1.5)$ & $2(3.1)$ & 0 & $2(3.1)$ \\
\hline $\mathrm{Feb}$ & 61 & $2(3.3)$ & $6(9.8)$ & $22(36.1)$ & 0 & $3(4.9)$ & $3(4.9)$ & $2(3.3)$ & 0 & $4(6.6)$ & $2(3.3)$ & $1(1.6)$ & $2(3.3)$ & 0 & $2(3.3)$ \\
\hline Mar & 49 & $2(4.1)$ & $2(4.1)$ & $9(18.4)$ & 0 & $1(2.0)$ & $1(2.0)$ & -6.1 & 0 & $2(4.1)$ & $3(6.1)$ & 0 & $1(2.0)$ & 4 & $1(2.0)$ \\
\hline Apr & 52 & $3(5.8)$ & $2(3.8)$ & $9(17.3)$ & 0 & $1(1.9)$ & $1(1.9)$ & $1(1.9)$ & 0 & $2(3.8)$ & $3(5.8)$ & 0 & $1(1.9)$ & 4 & $1(1.9)$ \\
\hline May & 83 & $1(1.2)$ & $2(2.4)$ & $4(4.8)$ & 0 & $2(2.4)$ & 0 & 0 & 0 & 0 & 0 & $2(2.4)$ & 0 & 9 & 0 \\
\hline June & 101 & $2(2.0)$ & $2(2.0)$ & $3(3.0)$ & 0 & 0 & 0 & $1(1.0)$ & 0 & 0 & 0 & $1(1.0)$ & 0 & 11 & 0 \\
\hline July & 90 & $2(2.2)$ & 0 & $2(2.2)$ & 0 & 0 & 0 & 0 & 0 & 0 & 0 & $1(1.1)$ & 0 & 13 & 0 \\
\hline Aug & 83 & $1(1.2)$ & 0 & $4(4.8)$ & 0 & 0 & 0 & 0 & 0 & 0 & 0 & 0 & 0 & 7 & 0 \\
\hline Sept & 75 & $4(5.3)$ & $2(2.7)$ & $4(5.3)$ & 0 & 0 & 0 & 0 & 0 & $2(2.7)$ & 0 & 0 & 0 & 0 & 0 \\
\hline Oct & 65 & $7(10.8)$ & $8(12.3)$ & $16(24.6)$ & $1(1.5)$ & $2(3.1)$ & $2(3.1)$ & 0 & $1(1.5)$ & $8(12.3)$ & $2(3.1)$ & $1(1.5)$ & $2(3.1)$ & 0 & $2(3.1)$ \\
\hline Nov & 70 & $8(11.4)$ & $6(8.6)$ & $20(28.6)$ & 0 & $3(4.3)$ & $3(4.3)$ & $2(2.9)$ & 0 & 7 (10.0) & $1(1.4)$ & $1(1.4)$ & $1(1.4)$ & 0 & $1(1.4)$ \\
\hline Dec & 74 & $10(13.5)$ & $2(2.7)$ & $17(23.0)$ & 0 & $1(1.4)$ & $1(1.4)$ & $3(4.1)$ & $1(1.4)$ & 11 (14.9) & $2(2.7)$ & 0 & $1(1.4)$ & 4 & $1(1.4)$ \\
\hline \multicolumn{16}{|l|}{2006} \\
\hline Feb & 62 & $3(4.8)$ & $4(6.5)$ & $18(29.0)$ & 0 & $2(3.2)$ & $3(4.8)$ & $2(3.2)$ & 0 & $3(4.8)$ & $2(3.2)$ & $1(1.6)$ & $3(4.8)$ & $2(3.2)$ & $3(4.8)$ \\
\hline May & 94 & $1(1.1)$ & 0 & $2(2.1)$ & 0 & $4(4.3)$ & $1(1.1)$ & 0 & 0 & $1(1.1)$ & 0 & 0 & 0 & $4(4.3)$ & 0 \\
\hline Oct & 91 & $7(7.7)$ & $3(3.3)$ & $15(16.5)$ & $1(1.1)$ & $6(6.6)$ & $2(2.2)$ & $2(2.2)$ & $1(1.1)$ & $9(9.9)$ & $5(5.5)$ & $3(3.3)$ & $2(2.2)$ & $2(2.2)$ & $2(2.2)$ \\
\hline \multicolumn{16}{|l|}{2007} \\
\hline Feb & 91 & $2(2.2)$ & $7(7.7)$ & $24(26.4)$ & $1(1.1)$ & $3(3.3)$ & $4(4.4)$ & $2(2.2)$ & $2(2.2)$ & $8(8.8)$ & $4(4.4)$ & $2(2.2)$ & $5(5.5)$ & $1(1.1)$ & $5(5.5)$ \\
\hline May & 108 & $2(1.9)$ & $2(1.9)$ & $3(2.8)$ & 0 & 0 & 0 & $1(0.9)$ & 0 & 0 & 0 & $1(0.9)$ & 0 & $\begin{array}{c}11(10.2 \\
)\end{array}$ & 0 \\
\hline Nov & 80 & $5(6.3)$ & $7(8.8)$ & $16(20.0)$ & $1(1.3)$ & $4(5.0)$ & $4(5.0)$ & $3(3.8)$ & $2(2.5)$ & $5(6.3)$ & $2(2.5)$ & $2(2.5)$ & $2(2.5)$ & $1(1.3)$ & $2(2.5)$ \\
\hline
\end{tabular}

salinity, electrical conductivity, and total dissolved solids were measured using 'Orion-5 Star' (Thermo-Orion, Scientific Equipment, USA) at standardized $25^{\circ} \mathrm{C}$. The sodium, potassium, and calcium in the acid-digested (nitric and perchloric acid) and air dried samples were analyzed using Flame photometer (ELICO-C1-360). Magnesium, iron, copper, and lead were analyzed using Atomic
Absorption Spectrophotometer (Varian Spectra AA200).

\section{STATISTICAL ANALYSIS OF DATA}

Q-mode cluster analysis based on Ward's method (Ward, 1963) was carried out to examine community groups in the species data using the PAST software (Hammer et al., 2001). Gradient 
TABLE 2b (continued).

\begin{tabular}{|c|c|c|c|c|c|c|c|c|c|c|c|c|c|c|c|}
\hline 2005 & 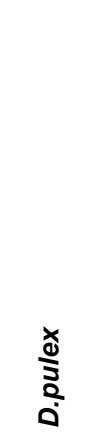 & 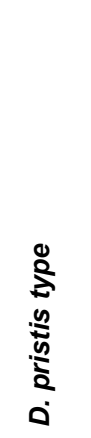 & 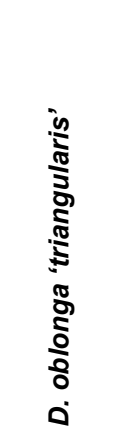 & 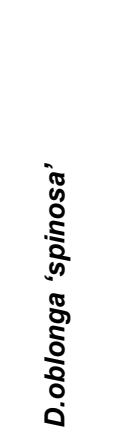 & 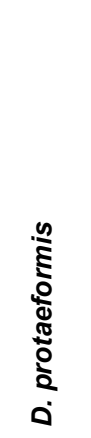 & 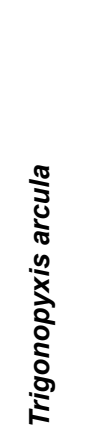 & 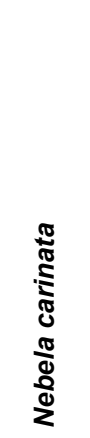 & $\begin{array}{l}\frac{\pi}{0} \\
\stackrel{\Xi}{\Xi} \\
i\end{array}$ & 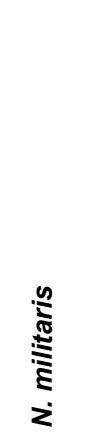 & 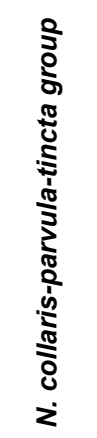 & 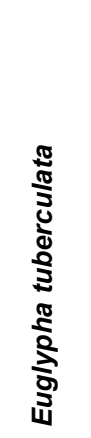 & 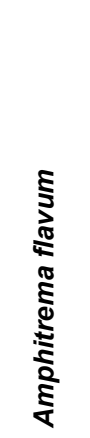 & 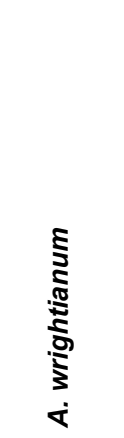 & 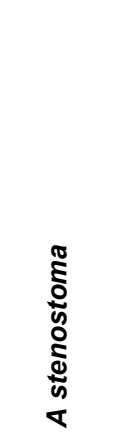 & 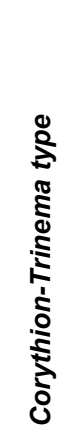 \\
\hline Jan & 0 & 0 & $1(1.5)$ & $1(1.5)$ & $2(3.1)$ & $2(3.1)$ & $1(1.5)$ & 0 & 0 & $2(3.1)$ & 0 & $1(1.5)$ & $1(1.5)$ & $2(3.1)$ & 0 \\
\hline Feb & 0 & $1(1.6)$ & $2(3.30$ & $1(1.6)$ & $1(1.6)$ & $3(4.9)$ & 0 & 0 & 0 & $1(1.6)$ & 0 & $1(1.6)$ & 0 & $4(6.6)$ & 0 \\
\hline Mar & 4 & $2(4.1)$ & $5(10.20$ & $4(8.2)$ & 0 & $2(4.1)$ & 0 & 0 & 0 & 0 & $1(2.0)$ & $2(4.1)$ & 0 & $4(8.2)$ & $1(2.0)$ \\
\hline Apr & 4 & $2(3.8)$ & $5(9.60$ & $4(7.7)$ & 0 & $2(3.8)$ & 0 & 0 & $1(1.9)$ & 0 & $3(5.8)$ & $3(5.8)$ & 0 & $4(7.7)$ & $1(1.9)$ \\
\hline May & 9 & 0 & $7(8.4)$ & $2(2.4)$ & $4(4.8)$ & $1(1.2)$ & $2(2.4)$ & $1(1.2)$ & $2(2.4)$ & 0 & $3(3.6)$ & $6(7.2)$ & 11(13.3) & $24(28.9)$ & 0 \\
\hline June & 11 & 0 & $21(20.8)$ & $8(7.9)$ & $3(3.0)$ & 0 & $2(2.0)$ & $1(1.1)$ & $3(3.0)$ & 0 & $4(4.0)$ & $3(3.0)$ & $8(7.9)$ & $21(20.8)$ & $7(6.9)$ \\
\hline July & 13 & 0 & 15 (16.7) & $7(7.8)$ & $6(6.7)$ & 0 & $2(2.2)$ & 0 & $2(2.2)$ & 0 & $2(2.2)$ & $2(2.2)$ & $9(10.0)$ & 19(21.1) & $8(8.9)$ \\
\hline Aug & 7 & 0 & $14(16.9)$ & $2(2.4)$ & $4(4.8)$ & 0 & $1(1.2)$ & 0 & $2(2.4)$ & 0 & $1(1.2)$ & $5(6.0)$ & $10(12.0)$ & $28(33.7)$ & $4(4.8)$ \\
\hline Sept & 0 & 0 & $12(16.0)$ & 292.7 & $3(4.0)$ & $2(2.7)$ & $1(1.3)$ & 0 & $1(1.3)$ & 0 & 0 & $3(4.0)$ & $8(10.7)$ & $25(33.3)$ & $6(8.0)$ \\
\hline Oct & 0 & 0 & $1(1.5)$ & $4(6.2)$ & $2(3.1)$ & $2(3.1)$ & $1(1.5)$ & 0 & 0 & 0 & 0 & $2(3.1)$ & $1(1.5)$ & $2(3.1)$ & 0 \\
\hline Nov & 0 & $1(1.4)$ & $2(2.9)$ & $3(4.3)$ & $1(1.4)$ & $3(4.3)$ & 0 & 0 & 0 & $1(1.4)$ & 0 & $3(4.30$ & 0 & $4(5.7)$ & 0 \\
\hline Dec & 4 & $2(2.7)$ & $5(6.8)$ & $4(5.4)$ & 0 & $2(2.7)$ & 0 & 0 & 0 & $1(1.4)$ & 0 & $2(2.7)$ & 0 & $4(5.4)$ & $1(1.4)$ \\
\hline \multicolumn{16}{|l|}{2006} \\
\hline Feb & $2(3.2)$ & $1(1.6)$ & $2(3.2)$ & $2(3.2)$ & $1(1.6)$ & $2(3.2)$ & 0 & 0 & 0 & $2(2.2)$ & $2(3.2)$ & $2(3.2)$ & $1(1.6)$ & $3(4.8)$ & $1(1.6)$ \\
\hline May & $4(4.3)$ & 0 & $12(12.8)$ & $14(14.9)$ & $3(3.2)$ & $3(3.2)$ & $3(3.2)$ & $2(2.1)$ & $1(1.1)$ & 0 & $2(2.1)$ & $8(8.50$ & $11(11.7)$ & $21(22.3)$ & $1(1.1)$ \\
\hline Oct & $2(2.2)$ & $1(1.1)$ & $5(5.5)$ & $7(7.7)$ & $2(2.2)$ & $3(3.3)$ & $1(1.1)$ & $1(1.1)$ & 0 & 0 & $1(1.1)$ & $3(3.3)$ & $4(4.4)$ & $5(5.5)$ & 0 \\
\hline \multicolumn{16}{|l|}{2007} \\
\hline Feb & $1(1.1)$ & 0 & $4(4.4)$ & $5(5.5)$ & $3(3.3)$ & $4(4.4)$ & $1(1.1)$ & $1(1.1)$ & $1(1.1)$ & 0 & $1(1.1)$ & $2(2.2)$ & $1(1.1)$ & $3(3.3)$ & 0 \\
\hline May & $\underset{)}{11(10.2}$ & 0 & 21(19.4) & $8(7.4)$ & $6(5.6)$ & $1(0.9)$ & $2(1.9)$ & $1(0.9)$ & $3(2.8)$ & $2(1.9)$ & $4(3.7)$ & $4(3.7)$ & $8(7.4)$ & $21(19.4)$ & $7(6.5)$ \\
\hline Nov & $1(1.3)$ & $1(1.3)$ & $1(1.3)$ & $4(5.0)$ & $2(2.5)$ & $2(2.5)$ & $1(1.3)$ & 0 & $1(1.3)$ & $1(1.3)$ & $1(1.3)$ & $3(3.8)$ & $2(2.5)$ & $5(6.3)$ & $2(2.5)$ \\
\hline
\end{tabular}

lengths in the data were examined using Detrended Correspondence Analysis (DCA). Redundancy Analysis (RDA) was then used to examine the relationships between thecamoebian taxa and environmental variables in the 2005 data. The analyses were carried out using Canoco version 4.5 (ter Braak, 2002).

\section{RESULTS AND DISCUSSION}

Since thecamoebians inhabit the sedimentwater interface they are highly susceptible to environmental and climatic response. Cluster analysis shows two major groups in the data; one characterized by samples taken from the late spring, summer,early fall and one characterized by samples taken from the late fall, winter, and early spring (Figure 6). DCA analysis showed that the gradient lengths are short, so linear-based ordination methods (e.g., RDA) are most suitable. RDA axes one $($ Eigenvalue $=0.797)$ and two (Eigenvalue $=0.082)$ explain $87.9 \%$ of the species-environment relationship (Figure 7). It is evident that a seasonal gradient is present across axis one as most samples from winter and fall are negatively correlated with it. The analysis illustrates that minimum, maxi- 


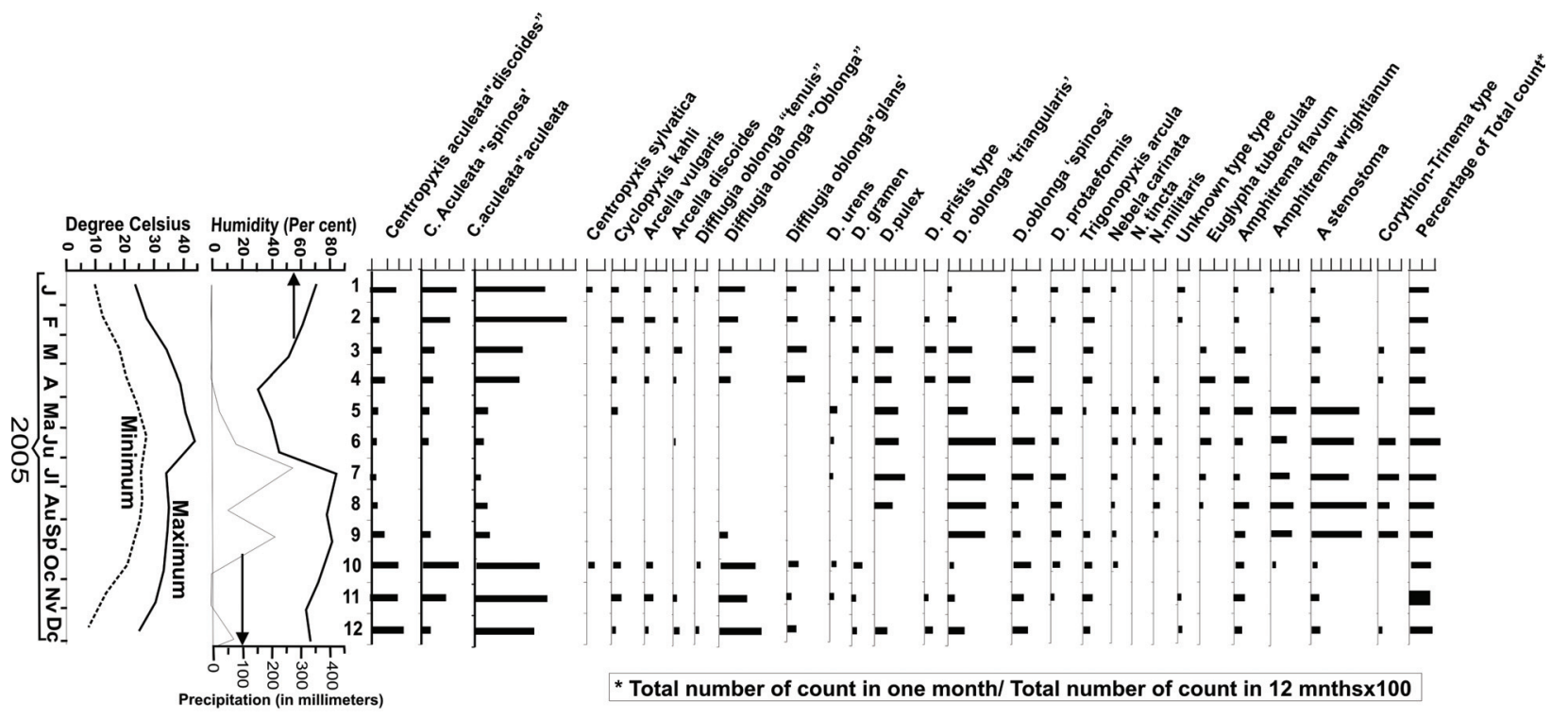

FIGURE 4. Annual percentage spectrum of thecamoebians in sediment-water interface samples from Lake Sadatal.

mum, and average temperature, $\mathrm{pH}, \mathrm{Cu}, \mathrm{Na}, \mathrm{K}, \mathrm{Fe}$, $\mathrm{Mg}$, electrical conductivity, total dissolved solids, and salinity are all strongly correlated with axis one. These variables vary significantly in relation to the seasonal changes. The three strongest controls appear to be $\mathrm{Na}, \mathrm{pH}$, and minimum temperature. Dissolved oxygen (DO) and $\mathrm{Pb}$ are not responding to this primary gradient and instead are correlated with axis two. Two clear groups of taxa and samples can be seen on the RDA diagram reflecting the seasonal variability of the assemblages. The samples on the right-hand side of axis 1 (in the direction of most of the environmental variables) are mostly from the spring and summer, and those on the left are mostly from fall and winter (Figure 7).

This analysis demonstrates clear relationships between thecamoebian species and their intraspecific "strains" to seasonal variations in the region, and to environmental factors in the Lake Sadatal. This lake is environmentally highly stressed because of extreme variations in seasonal temperature and humidity, biotic (seasonal variations in Lemna cover) and abiotic environmental variations, and high levels of anthropogenic dissolved chemicals (Table 1).

Percentages of thecamoebian taxa and "strains" recorded every month for the year of 2005 are shown in Figure 4, likewise similar data is presented for the months of February, May, and December for the years 2005, 2006, and 2007 (Figure 5). Some of the significant observations are as follows;
1. Highest percentages of Centropyxis aculeata and its strains 'aculeata', 'discoides,' and 'spinosa' are during winter months when maximum temperatures are $\sim 25^{\circ} \mathrm{C}$ and relative humidity is low.

2. Arcella vulgaris and Arcella discoides occur only during winter months and follow the same trend as centropixids.

3. Highest percentages of Amphitrema stenostoma and Amphitrema wrightianum are during summer months when maximum temperature can reach $\sim 45^{\circ} \mathrm{C}$, and relative humidity is high due to following monsoon season.

4. Difflugia oblonga "triangularis" is a significant form that occurs throughout the year but its proportion declines during cold winter months and is highest during summer and monsoon season.

5. Nebella spp. do not occur during winter months.

6. Distribution of difflugids is throughout the year. D. oblonga and its three "strains" like 'glans,' 'oblonga,' and 'tenuis' are absent from summer months. Their distribution is opposite of the distribution of Difflugia oblonga "triangularis."

7. The total concentration of thecamoebians was highest during summers particularly during the monsoon months when precipitation and humidity are very high.

8. Few difflugids, Nebella spp., and Euglypha 


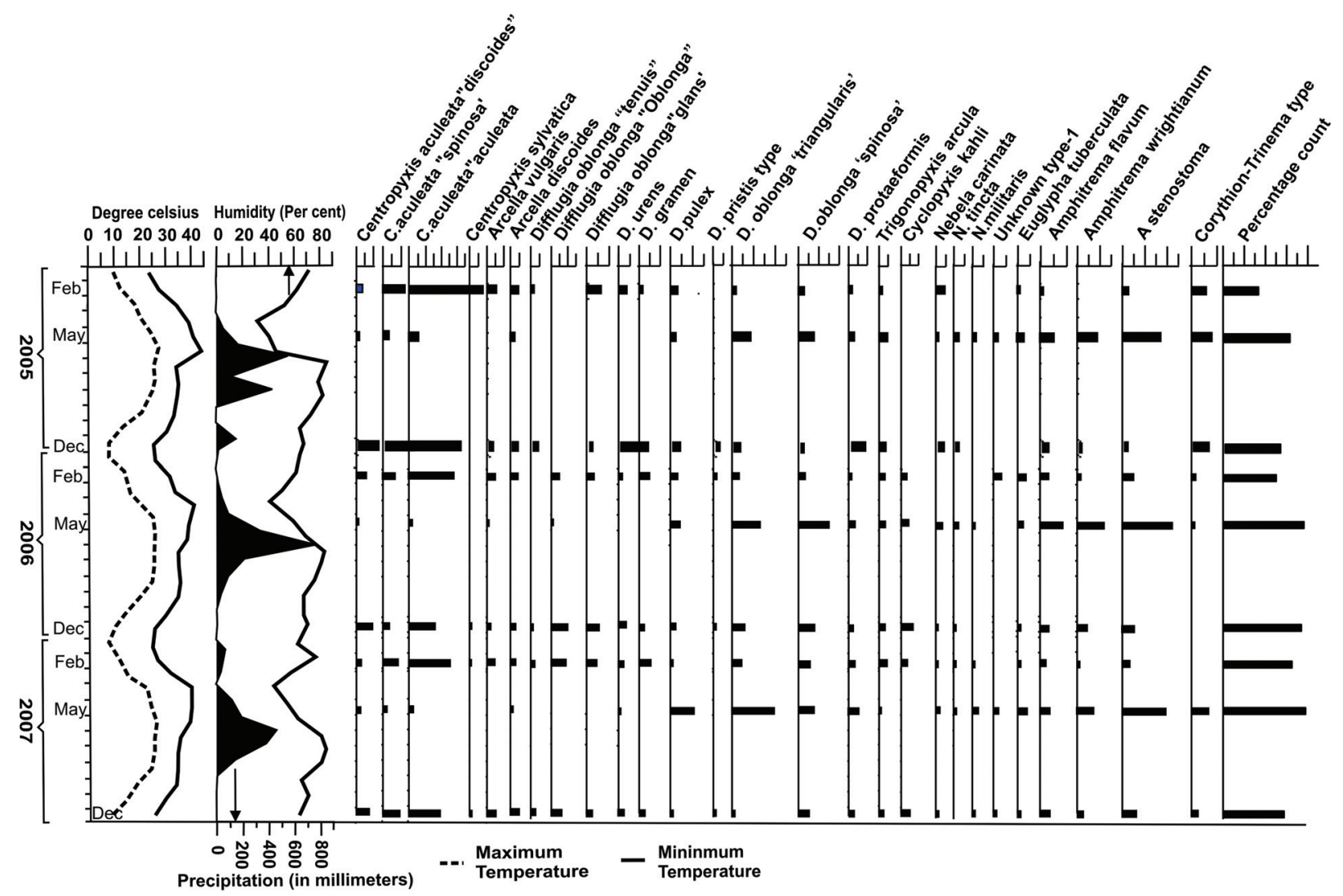

FIGURE 5. Percentage spectrum of thecamoebians in three subsequent years 2005-2007 (February, May and December) Each division $=5 \%$.

tuberculata survive eutrophic conditions developed during pre-monsoon summer months (April-mid June) and could be saprobes on organic detritus of Lemna fronds that settle down in the lake bed. During these months the lake level falls by almost $50 \%$. Thus, these species tend to survive in eutrophic conditions, low water level, high temperature, high salinity, and very low dissolved oxygen (DO).

9. Low thecamoebian counts during winter months are due to dryness that causes a decline in centropyxids.

10. Hydrological characteristics of thecamoebian habitat like running versus standing water is very important and can mask the effects of other physico-chemical variables of the lake. Thus they are sensitive indicators of hydrological conditions in both lakes and peatlands, primarily the depth of the water table. Our results illustrate a drastic change in testate amoebae community and their morphometric response to seasonally induced lake's hydrological changes.

\section{Thecamoebians in Chemically Stressed Lacustrine Environment}

Lacustrine thecamoebian assemblages are well-known indicators of pollution levels (Collins et al., 1990; Asioli et al., 1996; Patterson et al., 1996). Their species and intraspecific "strains" have also been successfully used as proxies to heavy metal pollution resulting from mine tailings in northern Ontario, Canada (Reinhardt et al., 1998), long- and short-term changes in lake bottom acidity (Kumar and Patterson, 2000), and contaminant indicators (Patterson and Kumar, $2000 \mathrm{a}$ and $\mathrm{b}$ ).

There are several thecamoebian species and "strains" in Sadatal, which were also commonly reported from chemically polluted lakes of Canada and Italy. The significant forms indicating stressed environments in Sadatal are Arcella vulgaris, Centropyxis aculeata and its "strains" like "aculeata," "discoides," and "spinosa," and they dominate the thecamoebian assemblage (Figures 4 and 5). Several difflugid forms along with other taxa are also present in the lake but their proportional representation usually is $<5 \%$. This lake is perennially under high level of environmental stress but the 
Q-MODE CLUSTER ANALYSIS

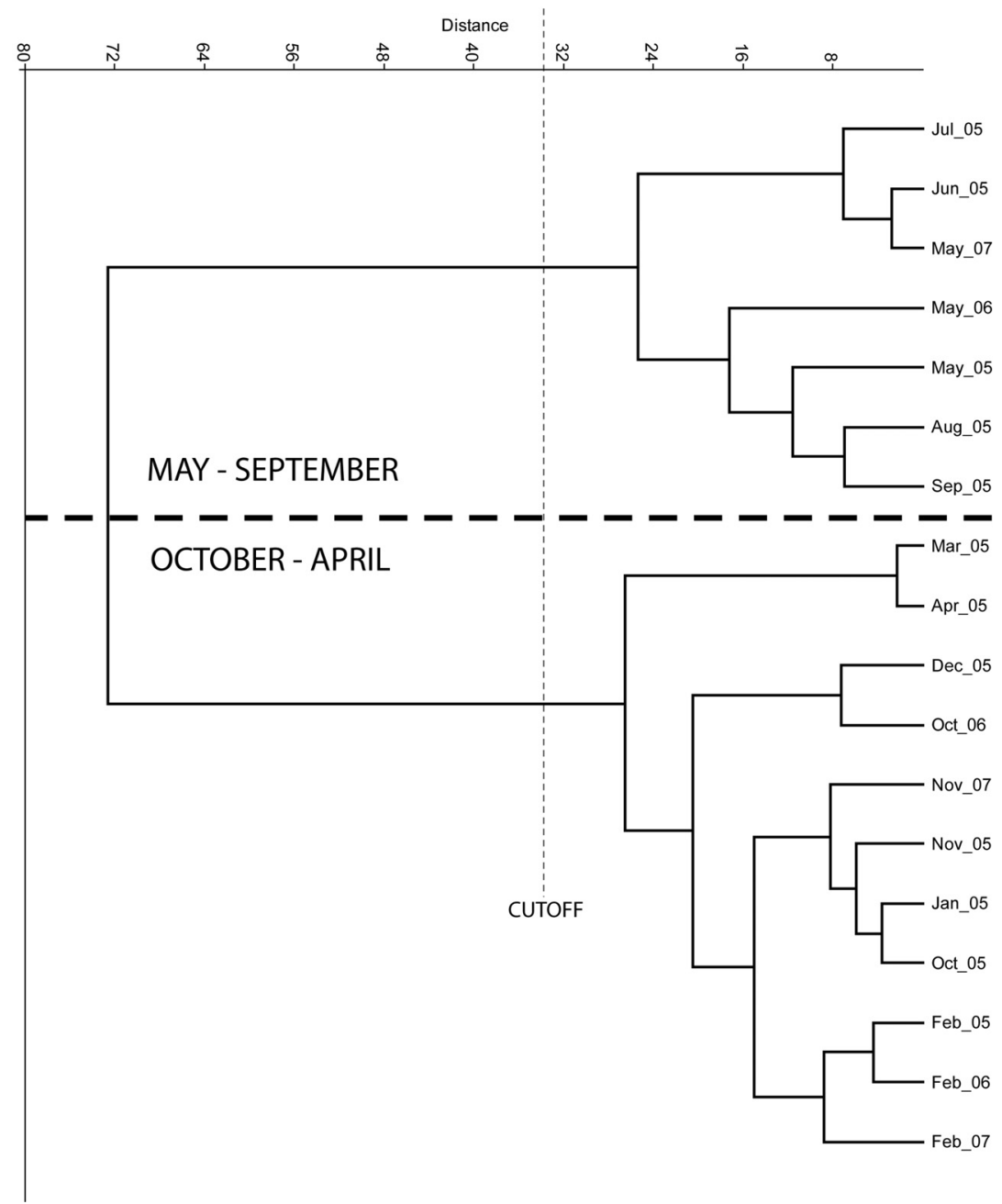

FIGURE 6. Q-mode cluster analysis dendrogram (Ward's method) of the 2005-2007 data .

stress reduces during monsoon season (JuneSeptember) when the lake level rises. During these months $A$. vulgaris almost disappears, and Centropyxids become a proportional minority, and Difflugids become a dominant group. This situation becomes reverse during rest of the year (Figures 4 and 5).

\section{Thecamoebian Assemblages in Response to Seasonality}

Holocene thecamoebian faunas in association with pollen successions have been used as proxies for record of climate change in Canadian lakes (McCarthy et al., 1995; Boudreau et al., 2005). In a similar study of Holocene thecamoebian faunas and succession of pollen assemblages from Swan Lake were used as indicators of land-use change and settlement history around environmentally sensitive Oak Ridge Moraine watershed in southern Ontario, Canada (Patterson et al., 2002). Dallimore et al. (2000) studied Holocene environmental of thermokarst lakes in the Northwest Territories, Canada using thecamoebians as paleolimnological indicators. Peatlands have been studied for decades to decipher Holocene climate change especially in the northern hemisphere. Both plant macrofossils and microfossils have been used. Thecamoebian faunas are also being successfully used for this purpose (Swindles et al., 2010).

Thecamoebian response to seasonal changes in the tropics has never been reported before. However, Neville et al. (2010a) show the use of thecamoebians to monitor seasonal environmental changes in oil sand reclamation wetlands in Northern Alberta, Canada. In Lake Sadatal Centropyxids and Arcellinids dominate the low humidity, low pre- 


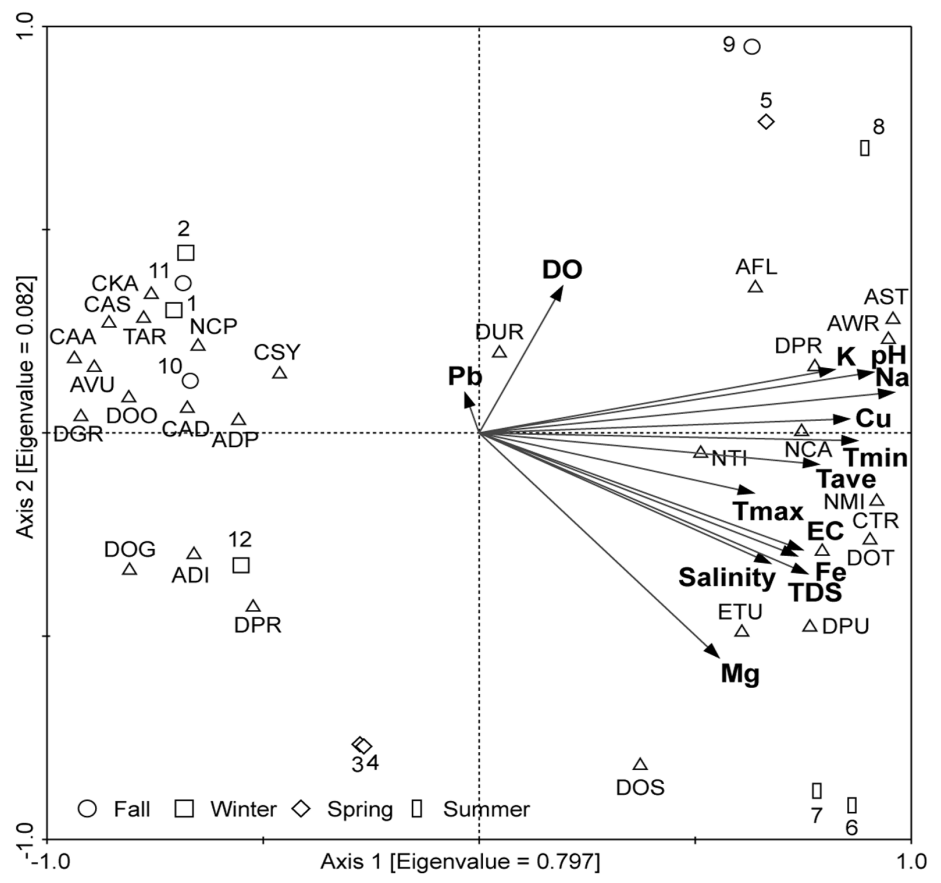

$\begin{array}{ll}\text { Code } & \text { Taxon } \\ \text { CAD } & \text { Centropyxis aculeata "discoides" } \\ \text { CAS } & \text { C. aculeata "spinosa" } \\ \text { CAA } & \text { C. aculeata "aculeata" } \\ \text { CSY } & \text { C. sylvatica type } \\ \text { CKA } & \text { Cyclopyxis kahlii } \\ \text { AVU } & \text { Arcella vulgaris } \\ \text { ADI } & \text { A. discoides } \\ \text { ADP } & \text { A. c.f. discoides var. pseudovulgaris } \\ \text { DOO } & \text { Difflugia oblonga "oblonga" } \\ \text { DOG } & \text { D. oblonga "glans" } \\ \text { DUR } & \text { D. urens } \\ \text { DGR } & \text { D. gramen } \\ \text { DPU } & \text { D. pulex } \\ \text { DPR } & \text { D. pristis type } \\ \text { DOT } & \text { D. oblonga 'triangularis' } \\ \text { DOS } & \text { D. oblonga 'spinosa' } \\ \text { DPR } & \text { D. protaeformis } \\ \text { TAR } & \text { Trigonopyxis arcula } \\ \text { NCA } & \text { Nebela carinata } \\ \text { NTI } & \text { N. tincta } \\ \text { NMI } & \text { N. militaris } \\ \text { NCP } & \text { N. collaris-parvula-tincta group } \\ \text { ETU } & \text { Euglypha tuberculata } \\ \text { AFL } & \text { Amphitrema flavum } \\ \text { AWR } & \text { A. wrightianum } \\ \text { AST } & \text { A. stenostoma } \\ \text { CTR } & \text { Corythion-Trinema type } \\ & \end{array}$

FIGURE 7. RDA triplot showing taxa, environmental variables and sample data for 2005. Sample codes 1-12 correspond to the month from January-December. The environmental variables include $\mathrm{pH}$, salinity (ppt), electrical conductivity $(\mathrm{mS} / \mathrm{cm})$, total dissolved solids $(\mathrm{mg} / \mathrm{l})$, average atmospheric temperature $\left({ }^{\circ} \mathrm{C}\right)$, minimum temperature $\left({ }^{\circ} \mathrm{C}\right)$, maximum temperature $\left({ }^{\circ} \mathrm{C}\right)$, dissolved oxygen in Water (mg/l), $\mathrm{Na}(\mathrm{mg} / \mathrm{g}), \mathrm{K}(\mathrm{mg} / \mathrm{g}), \mathrm{Mg}(\mathrm{mg} / \mathrm{g}), \mathrm{Fe}(\mathrm{mg} / \mathrm{g}), \mathrm{Cu}(\mathrm{mg} / \mathrm{g})$, $\mathrm{Pb}$ (mg/g).

cipitation cooler months (October-March) whereas Amphitrema spp. and Difflugids summer, high precipitation, and high humidity months (April-September). Dominance of Amphitrema spp. may be related to abundance of aquatic weed Lemna detritus at the lake bottom during summer (Figure 4 and 5). Total thecamoebian counts are higher during summer than winter.

\section{CONCLUSIONS}

1. Thecamoebian species and "strains" are reported from perennial Lake Sadatal situated near Mallanwan in the Ganga-Yamuna Plains of North India.

2. Lake Sadatal is a shallow (maximum depth $\sim 1.5 \mathrm{~m}$ during summer and $\sim 3.0 \mathrm{~m}$ during July-August monsoon season) remnant of a past oxbow lake left by meandering Ganga River and its tributaries.

3. This region shows strong seasonal changes resulting in very high variation in the average summer and winter temperature, and humidity.

4. Taxonomically diverse and mixed thecamoebi- ans that are known to occur in lakes and peatlands in different parts of the world were recovered from Lake Sadatal showing distinct summer and winter communities for three years (2005-2007).

5. A strong seasonal control on the thecamoebians present is illustrated through cluster and redundancy analysis (RDA). RDA shows the strong control of minimum, maximum, and average temperature, $\mathrm{pH}, \mathrm{Cu}, \mathrm{Na}, \mathrm{K}, \mathrm{Fe}, \mathrm{Mg}$, electrical conductivity, total dissolved solids, and salinity on the thecamoebian communities.

6. Centropyxids and Arcellenids dominated the low humidity, low precipitation cooler months (October-March) whereas Amphitrema spp. and Difflugia oblonga "triangularis" dominate summer and high precipitation, high humidity monsoon months (April-September).

7. Dominance of Amphitrema spp. is most likely related to abundance of aquatic weed Lemna detritus at the lake bottom during summer.

8. Total counts of thecamoebians were higher during summer than winter. 


\section{Thecamoebian Taxa Recovered in This Study and Their Short Descriptions}

Since this study is based on acid resistant thecamoebians from a tropical lake with peculiar physical and chemical environment a short description is deemed necessary for the forms recovered. The present forms appear to be sturdier than their counterparts from the temperate regions. There is a general trend also in diminishing size of these taxa in comparison to the ones known from the northern hemisphere but over all morphological characters are common.

Phylum: PROTOZOA Goldfuss, 1818

Subphylum: SARCODINA Schmarda, 1871

Class: RHIZOPODA von Siebold, 1845

Subclass: LOBOSA Carpenter, 1861

Order: ARCELLINIDA Kent, 1880

Family: CENTROPYXIDAE Jung, 1942

\section{Centropyxis Stein, 1859}

Centropyxis aculeata "aculeata" Reinhardt et al., 1998 (Figure 8-1): Test diameter 70-80 $\mu \mathrm{m}$, circular, ovoid, or discoid; aperture 20-25 $\mu \mathrm{m}$, eccentric, circular or ovoidal, often with a lobate border; spine length not exceeding more than $10 \mu \mathrm{m}$, slightly curved, and with a gentle curve at the tip; aperture rounded or slightly invaginated at 4-5 angular points; shell mostly membranous, reticulate, encrusted with moderate and even size foreign particles or sandy material.

C. aculeata "spinosa" Reinhardt et al., 1998 (Figure 8-2): Test diameter $60-80 \mu \mathrm{m}$, ovoid, or discoid; aperture $25-30 \mu \mathrm{m}$, eccentric and circular, spines $8-11$, are about $20 \mu \mathrm{m}$ in length, straight, broad at base with sharply pointed tip. Tests are generally membranous, finely reticulate, encrusted with foreign particles, or sandy material. The size of the test and number of spines shows similarity with those recorded in Japan (Saitama Website 1999, 9 spines).

C. aculeata"discoides" Reinhardt et al., 1998 (Figure 8-3): Test diameter 30-40 $\mu \mathrm{m}$ "doughnut" shaped, without spines. Test shape ovoid to oblong, pseudostome eccentric, circular measuring 20-25 $\mu \mathrm{m}$, wall composed of either numerous alveoli arranged in layers or agglutinated mineral particles; aperture sub-terminal or occasionally central.

Centropyxis arcelloides Penard, 1902 (Figure 84): Test size $70-80 \mu \mathrm{m}$, circular or discoid, no spines, wall finely reticulate with adhering fine sand or organic particles. Aperture circular measuring $25-30 \mu \mathrm{m}$, which is about half the diameter of the shell in width. It occurs associated with the Lemna weed.

C. sylvatica Deflandre, 1929 (Figure 8-5): Test length varies between $35-40 \mu \mathrm{m}$, and width between 30-35 $\mu \mathrm{m}$. The shell is oval and in ventral view almost circular with a sub-terminal aperture of diameter15-20 $\mu \mathrm{m}$. The surface of the shell is almost smooth. This form is similar to $C$. aerophila and C. aerophila var. sphagnicola.

\section{Family Arcellidae Ehrenberg, 1843}

Arcella vulgaris Ehrenberg, 1830 (Figures 8-6, 7): Can be distinguished from Centropyxis aculeata "discoides" by absence of agglutinated particles. The test is hyaline and almost transparent measuring 40-55 $\mu \mathrm{m}$, circular to slightly oval in dorso-ventral view, made of proteinaceous matter, surface smooth or punctuate occasionally with honeycomb like reticulation. Aperture central and circular, margin not well defined measuring 15-20 $\mu \mathrm{m}$.

Arcella discoides Ehrenberg, 1843 (Figure 8-8): Test diameter $60-70 \mu \mathrm{m}$, circular in front view, diameter about three to four times the height; test appearance and body structure similar to $A$. vulgaris; but without a distinct border. Shell smooth, circular aperture with one-fourth size of the diameter, margin well defined with few small pores around the aperture. The whole of the shell surface appears to have few small pores, although they are less apparent on the basal collar.

Arcella artocrea type Leidy, 1876 (Figure 8-9): Test measures 50-55 $\mu \mathrm{m}$ with a distinct and welldefined border, surface with honey-comb like structure, pitted, or mammillated. The shell is brown, perfectly circular. The basal collar is usually prominent and smooth. The aperture is small $(10 \mu \mathrm{m})$ circular and rimmed.

\section{Family: Cyclopyxidae Schönborn, 1989}

Cyclopyxis type Deflandre, 1929 (Figure 8-10): Test circular with organic matrix and reticulate surface. Pseudostome central, round, or slightly irregular, margin not very distinct, large $(12-15 \mu \mathrm{m})$ and equal to the radius of the test.

Trigonopyxis type Leidy, 1879 (Figures 8-11, 12): The diameter of shell is $30-35 \mu \mathrm{m}$. Central aperture less than 10 um, circular, invaginated, or triangular, surrounded by a thin ring of organic cement. Shell spherical with broadly reticulated surface that becomes finer towards the pseudostome. Shell margin well defined and surface covered with inorganic particles of variable size and shape. 

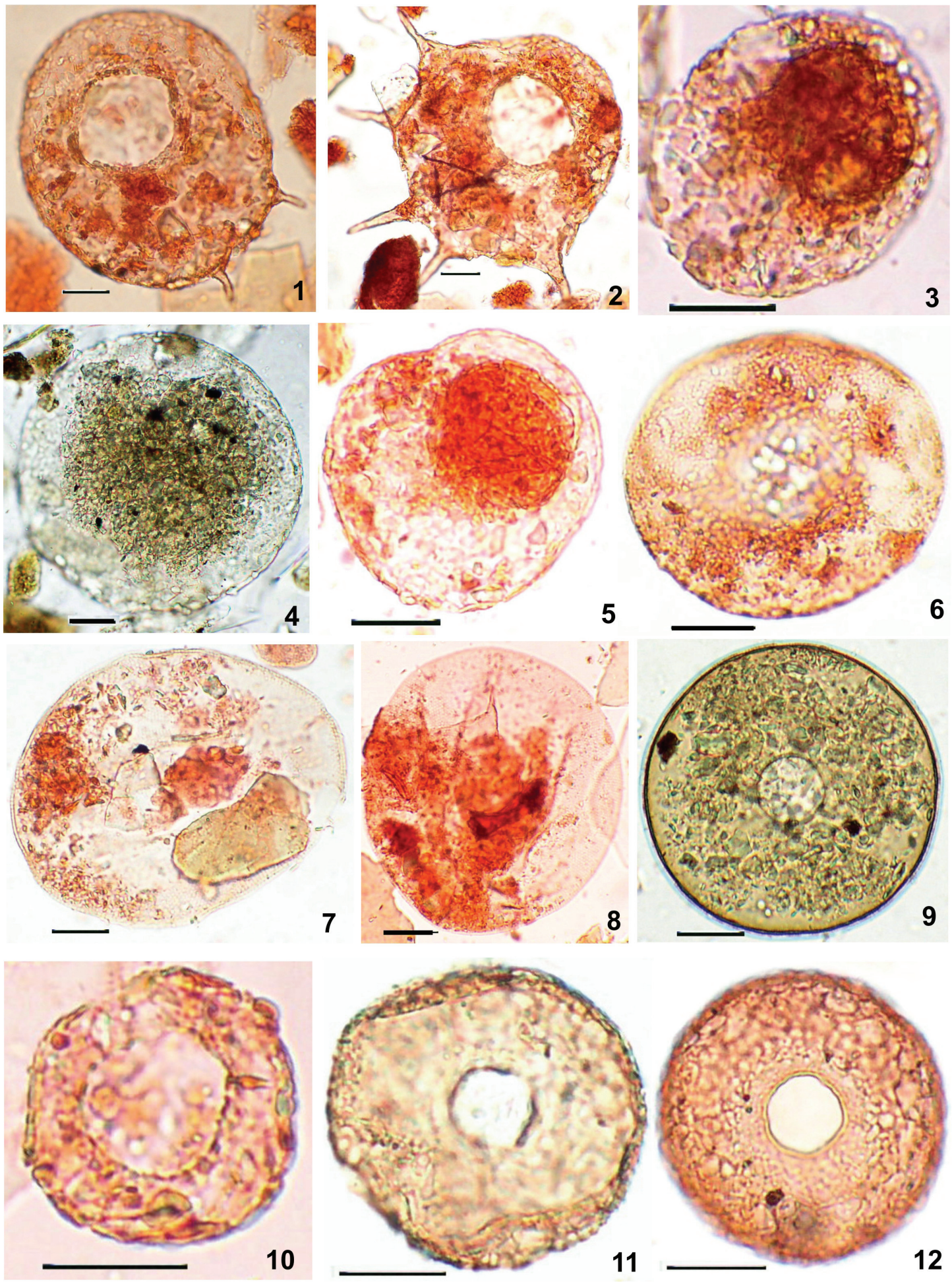

\section{All bars $=10 \mu \mathrm{m}$}

FIGURE 8. Photograph of described thecamoebian specimens, taken under high power light microscope (OlympusBX2). 1. Centropyxis aculeata "aculeata" Reinhardt et al., 1998; 2 C. aculeata "spinosa" Reinhardt et al., $1998 ; 3$. C. aculeata"discoides" Reinhardt et al., 1998; 4. Centropyxis arcelloides Penard, 1902; 5. C. sylvatica Deflandre, 1929; 6., 7. Arcella vulgaris Ehrenberg 1830; 8. Arcella discoides Ehrenberg, 1843; 9. Arcella artocrea type Leidy, 1876; 10. Cyclopyxis type Deflandre,1929; 11,12. Trigonopyxis type Leidy, 1879. 


\section{Family Difflugidae Stein, 1859}

Difflugia oblonga "oblonga" Reinhardt et al., 1998 (Figures 9-1, 2, 3): Test pyriform, flaskshaped, ovoid basal part, neck variable in length, or slightly flattened at the base, test composed of angular sand-grains and diatom frustules, 15-25 $\mu \mathrm{m}$ wide and $25-40 \mu \mathrm{m}$ long. Aperture is terminal, measuring $10 \mu \mathrm{m}$ in diameter, typically circular and lacking a collar.

Difflugia oblonga"glans" Reinhardt et al., 1998 (Figure 9-4): Test width measures 20-25 $\mu \mathrm{m}$ and length $40-50 \mu \mathrm{m}$, oblong with rounded fundus, wall composed of angular sand-grains or organic particles, aperture terminal, invaginated, and circular measuring about 10-15 $\mu \mathrm{m}$.

Difflugia gramen Penard, 1902 (Figure 9-5): Test oblong, slightly tapered at apertural end, wall smooth with fine reticulate patterns having small agglutinated particles mainly of sand grains. Test width measures 20-25 $\mu \mathrm{m}$ and length 35-40 $\mu \mathrm{m}$. Aperture measures $10-15 \mu \mathrm{m}$, terminal, with three to four petal-shaped lobes, delimited by a slightly raised irregular ridge. The present specimen revealed a very smooth texture.

Difflugia globulosa Dujardin, 1837 (Figure 9-6): Test egg-shaped, measuring $15-20 \mu \mathrm{m}$ in width and 20-25 $\mu \mathrm{m}$ in length. Wall with agglutinated sand-grains and organic matter. Aperture wide measuring more than $10 \mu \mathrm{m}$, margin well defined but no collar like structure.

Difflugia pulex type Penard, 1902 (Figure 9-7): Test oblong with a well-defined margin, measuring $25-30 \mu \mathrm{m}$. Aperture is terminal that ends in a very small neck $(5 \mu \mathrm{m})$, margin of the neck is irregular.

Difflugia lobostoma type Leidy, 1879 (Figure 9-8): Test globose to ovoid measuring $25 \mu \mathrm{m}$ in width and $30-35 \mu \mathrm{m}$ in length. Margin is irregular densely covered by sand grains of irregular size. Aperture terminal, measuring less than $10 \mu \mathrm{m}$.

Difflugia pristis type Penard, 1902 (Figure 9-9): Test oval or oblong measuring $15-20 \mu \mathrm{m}$ in width and $35-40 \mu \mathrm{m}$ in length; wall smooth with fine reticulation. Small neck ending in a small $(5 \mu \mathrm{m})$ pseudostome, lacking lobed collar.

\section{Family: Hyalospheniidae Schulze, 1877}

Nebela carinata Archer, 1867 (Figure 9-12): The shell is pyriform measures $20 \mu \mathrm{m}$ in width at the posterior end and length is $24-30 \mu \mathrm{m}$, has slightly extended neck. The aperture is round and sur- rounded by a thin collar of organic cement.

Nebela sp. (Figure 9-13): The length of shell is 20$25 \mu \mathrm{m}$, and the width $15-20 \mu \mathrm{m}$. It is drop-like, laterally strongly flattened.

Nebela tincta type (Figure 9-14): Test flaskshaped, with a slight neck, test 25-30 $\mu \mathrm{m}$ long and 12-15 $\mu \mathrm{m}$ wide, pseudostome $5 \mu \mathrm{m}$ wide.

\section{Family: Trinematidae Hoogenraad et Groot, 1940}

Certisella type (Figure 9-15): Test flask-shaped, elongated neck with terminal pseudostome. A frilled organic rim extends around the body as a collar, is prominent at the sub-terminal end. The base measures $10 \mu \mathrm{m}$ and the length is $60-70 \mu \mathrm{m}$. The collar measures about $10-12 \mu \mathrm{m}$ in diameter.

Corythion dubium Taranek, 1881 (Figure 9-16): Test length is $15 \mu \mathrm{m}$ and the width $10 \mu \mathrm{m}$ is ovoid and flattened. The subterminal aperture $(2 \mu \mathrm{m})$ is circular to oval, invaginated. These specimens are very small.

Amphitrema wrightianum Archer, 1869 (Figure 917): Test smooth proteinaceous and with distinct collared apertures at both poles, which measure 1$1.5 \mu \mathrm{m}$. It is $20-25 \mu \mathrm{m}$ long and $15-20 \mu \mathrm{m}$ wide.

A. stenostoma Nusslin, 1884 (Figure 9-18): Test is 20-25 $\mu \mathrm{m}$ long and 10-12 $\mu \mathrm{m}$ wide having two pseudostomes at opposite ends; the size of the pseudostome is $2-3 \mu \mathrm{m}$, the anterior pseudostome is wider than posterior one that appears like a tail.

Amphitrema flavum Archer, 1869 (Figure 9-19, 20): Test linear or ovoid, symmetrical, compressed, composed of a smooth proteinaceous test with or without adherent extraneous particles. It measures 25-30 $\mu \mathrm{m}$ long and $15 \mu \mathrm{m}$ wide. It has a circular aperture at both poles measuring about $10 \mu \mathrm{m}$.

?Amphitrema type (Figure 9-10, 11).

Figures 10-1, 2, and 3 are unidentified loricated bodies showing affinity with rhizopods with hyaline body of similar character but variable in size.

Figure 10-4 shows a similar inclusion inside the Centropyxis sp.

Figures $10-8,9,10,11,12$, and 13 present tests showing affinity with testate amoebae in shape and pseudostome like features suggesting the cyst formation of Centropyxids during unfavourable environmental conditions. With the onset of favourable winter conditions and oligotrophic state these perhaps regain vitality and grow. 


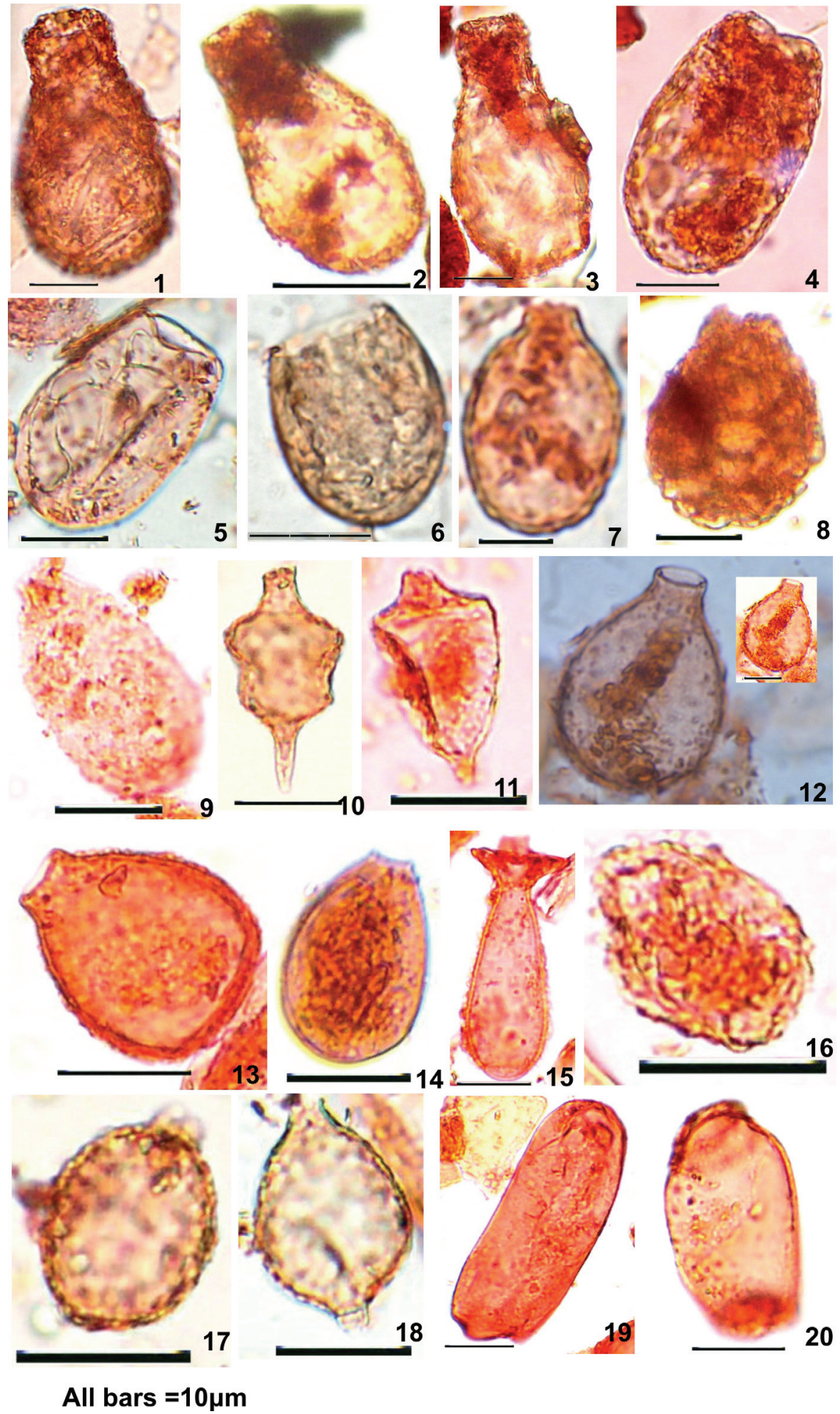

FIGURE 9. Photograph of described thecamoebian specimens, taken under high power light microscope (OlympusBX2). 1, 2, 3: Difflugia oblonga "oblonga" Reinhardt et al., 1998; 4. Difflugia oblonga"glans' Reinhardt et al., 1998; 5. Difflugia gramen Penard, 1902; 6. Difflugia globulosa Dujardin, 1837; 7. Difflugia pulex type Penard, 1902; 8. Difflugia lobostoma type Leidy, 1879; 9. Difflugia pristis type Penard, 1902; 10, 11. ?Amphitrema type; 12: Nebella carinata Archer, 1867; 13. Nebella sp.; 14. Nebella tincta type; 15. Certisella type; 16. Corythion dubium Taranek, 1881; 17. Amphitrema wrightianum Archer, 1869; 18. Amphitrema stenostoma Nusslin, 1884; 19., 20. Amphitrema flavum Archer 1869. 

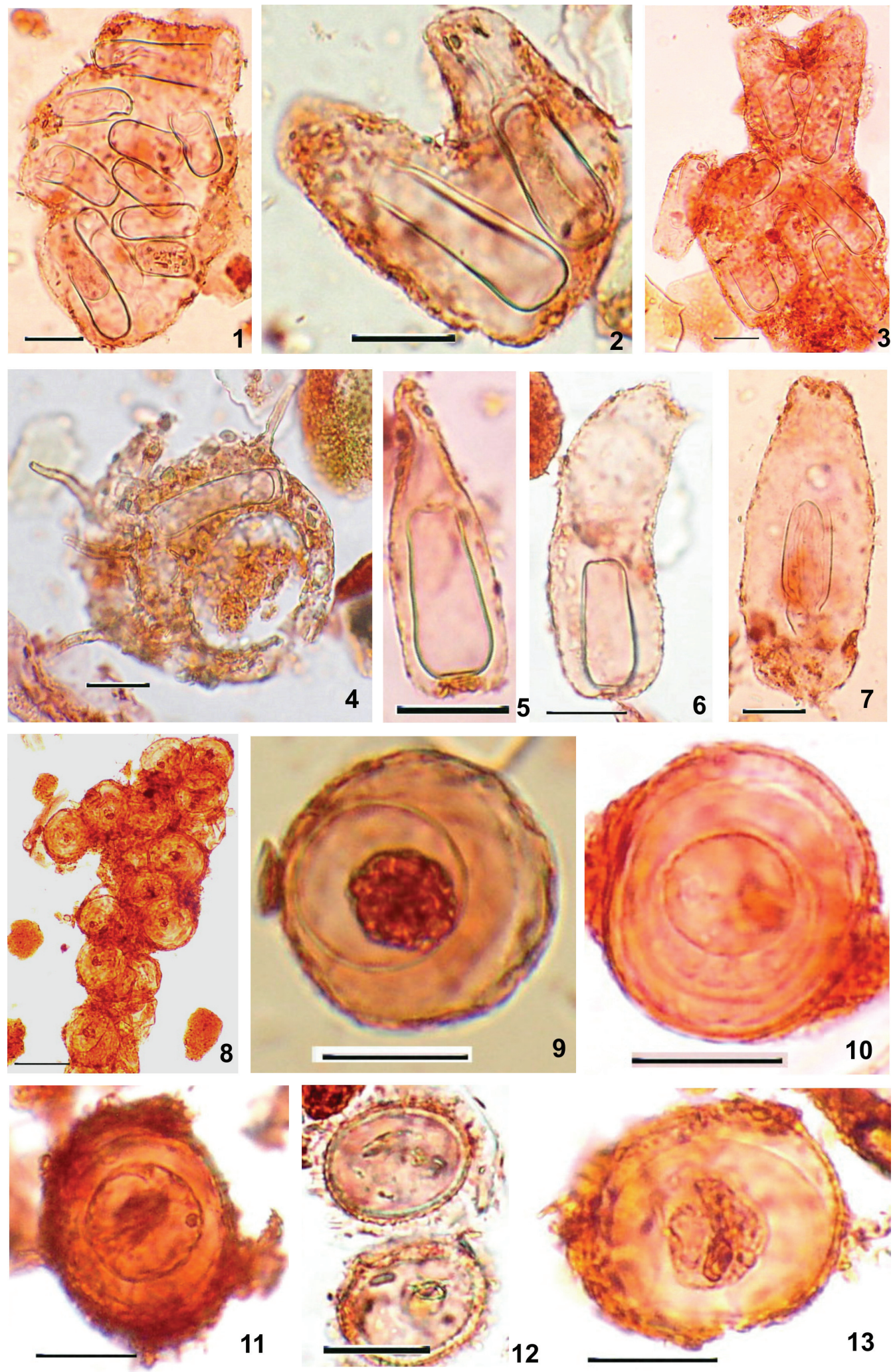

\section{All bars $=10 \mu \mathrm{m}$}

FIGURE 10. Photograph of described thecamoebian specimens, taken under high power light microscope (OlympusBX2). 1-3. Unidentified Form A; 4. inclusion inside the Centropyxis sp., 5-7. Loxophyllum elegans; 8-13. ?testate amoebae cyst. 


\section{Family: Amphileptidae Bütschlii, 1889}

Loxophyllum elegans Dujardin, 1841 Figures 10- 5, 6 , and 7 ; This is a medium-sized, predatory ciliate, body flattened.

\section{ACKNOWLEDGEMENTS}

We express our sincere gratitude to Prof. R.T. Patterson of Carleton University, Ottawa, Canada, for many suggestions to improve the quality of this paper. A. Farooqui thanks the Director, B. Sahni Institute of Palaeobotany, Lucknow, India, and A. Kumar thanks King Fahd University of Petroleum and Minerals, Dhahran, Saudi Arabia, for permission to publish this paper.

\section{REFERENCES}

Archer, W. 1867. "No title". (Remarks on freshwater Rhizopoda). Quarterly Journal of Microscopical Science, new series, 7:173-174.

Archer, W. 1869. On some fresh-water Rhizopoda, new or little-known. A Quarterly Journal of Microscopical Science, new series, 9:250-271.

Asioli, A., Medioli, F.S. and Patterson, R.T. 1996. Thecamoebians as a tool for reconstruction of paleoenvironments in some Italian lakes in the foothills of the southern Alps (Orta, Varese and Candia). Journal of Foraminiferal Research, 26:248-263.

Beyens, L. and Chardez, D. 1995. An annotated list of testate amoebae observed in the Arctic between the longitudes of $27^{\circ} \mathrm{E}$ and $168^{\circ} \mathrm{W}$. Archiv fuer Protistenkunde, 146:219-233.

Beyens, L., De Bock, P., and Jacques, E. 1990. Ecology of terrestrial testate amoebae from coastal lowlands on Devon Island (NWT, Canadian Arctic). Polar Biology, 10:431-440.

Boudreau, R.E.A., Galloway, J., Patterson, R.E., Kumar, A., and Michel, F.A. 2005. A paleolimnological record of Holocene climate and environmental change in the Temagami region, northeastern Ontario. Journal of Paleolimnology, 33:445-461.

Bütschlii, O. 1889. Protozoa. Mit einem Beitrag: Palaeontologische Entwicklung der Rhizopoda, von C. Schwager. In Bronn, H.G. (ed.), Die Klassen und Ordnungen des Thierreichs, wissenschaftlich dargestellt in Wort und Bild. Volume 3. 1887-1889, Abtheilung: Infusoria und System der Radiolaria, p. I-VII, 1098-2035, pls. 56-79. Winter'sche Verlagsbuchhandlung (Leipzig),

Carpenter, W.B. 1861. On the systematic arrangement of the Rhizopoda. Natural History Review (Dublin and London), new series, 1:456-472.

Carter, H.J., 1856. Notes on the fresh water Infusoria of the Island of Bombay. No. 1. Organization. Annals and Magazine of Natural History, series 2, 18 (105):221-249.
Carter, H.J. 1864.On fresh water Rhizopoda of England and India. Annals and Magazine of Natural History, series 3, 13:18-39.

Charman, D., Hendon, D., and Woodland, W. 2000. The identification of peatland testate amoebae. Quaternary Research Association Technical Guide no. 9, London.

Charman, D., Roe, H.M., and Gehrels, W.R. 2002. Modern distribution of saltmarsh testate amoebae: regional variability of zonation and response to environmental variables. Journal of Quaternary Science, 17 (5-6):387-409.

Collins, E.S., McCarty, F.M., Medioli, F.S., Scott, D.B., and Honig, C.A. 1990. Biogeographic distribution of modern thecamoebians in a transect along the eastern North Americam coast. In Hemleben, C. Kaminsky, M.A., Kuhnt, W., and Scott, D.B. (eds.), Paleoecology, Biostratigraphy, Paleoceanography and Taxonomy of Agglutinated Foraminifera, NATO Advanced Study Institute series, Series C, Mathematical and Physical Sciences, 327:783-791.

Dalby, A.P., Kumar, A., Moore, J.M. and Patterson, R.T. 2000. Preliminary survey of Arcellaceans (Thecamoebians) as limnological indicators in tropical lake Sentani, Irian Jaya, Indonesia. Journal of Foraminiferal Research, 30(2):135-142.

Dallimore, A., Schröder-Adams, C.J. and Dallimore, S.R., 2000. Holocene environmental history of thermokarst lakes on Richards Island, Northwest Territories, Canada: thecamoebians as paleolimnological indicators. Journal of Paleolimnology, 23:261283.

Deflandre, G. 1929. Observations sur les mouvements propres, pistes et vitesses de déplacement de quelques Protistes. Annales de Protistologie, 2:1-40.

Dujardin, F. 1837. Sur une nouvelle espèce de Gromia et sur les Difflugies. Annales des sciences Naturelles, Zoologie, ser. 2, 8:310-313.

Dujardin, F. 1841. Histoire naturelle des Zoophytes. Infusoires, comprenant la physiologie et la classification de ces animaux, et la manière de les étudier à l'aide du microscope: De Roret, collection "Nouvelle suites a Buffon, formant, avec les oeuvres de cet auteur, un cours complet d'Histoire naturelle." (Paris). Text volume (pp. I-XII, and 1-684) and Atlas of plates (pp. 114).

Ehrenberg, G.C. 1830. Organisation, Systematik und geographisches Verhältnis der Infusionsthierchen. Druckerei der Königlichen Akademie der Wissenschaften, Berlin.

Ehrenberg, G.C. 1843. Verbreitung und Einfluss des mikroskopischen Lebens in Süd- und Nord-Amerika. Abhandlungen der Königliche Akademie der Wissenschaften zu Berlin (1841), p. 291-446.

Erdtman, G.1943. An Introduction to pollen analysis. Chronica Botanica Co., Waltham, Mass, US. 
Escobar, J.H. and Martinez, J.I. 2008. Thecamoebians (Arcellaceans) as environmental and paleoenvironmental indicators in tropical fresh water: study at "La Fe" dam, Antioquia, Colombia. (http://www.geocities.com/CapeCanaveral/Launchpad/4680/Ingles/ Thecamoebian.html?20)

Farooqui, A. and Gaur, A. S. 2007. Arcellaceans and pollen/spores of a late Harappan settlement near Porbandar, west coast of India: Implications for palaeoecology and environmental monitoring. Current Science, 92(7):992-998.

Goldfuss, G.A. 1818. Probe aus Goldfuss Handbuch der Zoologie: An Herrn Hofrath Oken, Isis Order Encyclopadische Zeitung von Oken, 1:1670-1676.

Green, J. 1963. Zooplankton of the river Sokoto, the Rhizopoda testacea. Proceedings of the Zoological Society, 141:497-514.

Green, J. 1975. Fresh water ecology in Mato Grasso, Central Brazil IV: associations of testate rhizopoda. Journal of Natural History, 9:545-560.

Haman, D., and Kohl, B. 1994. A thecamoebinid assemblage from Lake Cocococha, Tambopata Reserve, Madre de Dios Province, Southeastern Peru. Journal of Foraminiferal Research, 24:226-232.

Hammer, O., Harper, D.A.T., and Ryan, P.D. 2001. PAST: Paleontological statistics software package for education and analysis, Palaeontologia Electronica 4.1.4:9 pp., $178 \mathrm{kB}$; http://palaeo-electronica.org/ 2001_1/past/issue1_01.htm

Hoogenraad, H.R. and Groot, A.A. 1940. Moosbewohnende thekamoebe Rhizopoden von Java und Sumatra. Treubia, 17:209-256.

Hoogenraad, H.R., and Groot, A.A. 1946. Thekamoebe sphagnumrhizopoden van Buitenzorg (Java). Biologische Jaarboek, Dodonea (Gent), 13:112-126.

Jung, W. 1942. Illustrierte Thekamöben-Bestimmungstabellen. I. Die Systematik der Nebelinen. Archiv für Protistenkunde, 95:357-390.

Kent, W.S. 1880-81. A manual of the Infusoria: including a description of all known flagellate, ciliate, and tentaculiferous Protozoa, British and foreign, and an account of the organization and affinities of the sponges: (1880-81). D. Bogue, London.

Kumar, A. 2011. Acid resistant Cretaceous thecamoebian tests from the Arabian Peninsula: suggestion for palynological study of agglutinated rhizopods. Journal of Micropalaeontology, 30:1-5.

Kumar, A. and Dalby, A.P.1998. Identification key for Holocene lacustrine arcellacean (thecamoebian) taxa. Palaeontologia Electronica, 1.1:35 pp, 3.1 MB;

http://www-odp.tamu.edu/paleo/index.htm.

Kumar, A. and Patterson, R.T. 2000. Arcellaceans (Thecamoebians): New tools for monitoring long-and short-term changes in lake bottom acidity. Environmental Geology, 39 (6):689-697.

Kumar, A. and Patterson, R.T. 2002. Dinoflagellate cyst assemblages from Effingham Inlet, Vancouver Island, British Columbia, Canada. Paleogeography, Plaeoclimatology, Paleoecology, 180:187-206.
Kumar, A. Farooqui, A., and Jha, N. 2011.Early Permian glacio-marine thecamoebian assemblages from the northwest Himalayas, India. Journal of Micropalaeontology, 30:75-89.

Leidy, J. 1876. Remarks on Arcella etc. Proceedings of the Academy of Natural Sciences of Philadelphia, 3rd series, 28:54-58.

Leidy, J. 1879. Fresh-water Rhizopods of North America: Report of the United States Geological Survey of the Territories, 12: I-XI, 1-324.

Loeblich, A.R., Jr., and Tappan, H. 1964. Sarcodina, chiefly 'Thecamoebians' and Foraminiferida. In Moore, R.C. (ed.), Treatise of Invertebrate Paleontology, Part C, Protista 2. Geological Society of America and University of Kansas Press, Lawrence, Kansas, p. 1-900.

McCarthy, F., Collins, E., McAndrews, J., Kerr, H., Scott, D.B., and Medioli, F. 1995. A comparison of postglacial arcellacean ("Thecamoebian") and pollen succession in atlantic Canada, illustrating the potential of arcellaceans for paleoclimatic reconstruction. Journal of Paleontology, 69:980-993.

Medioli, F.S. and Scott, D.B.1983. Holocene Arcellacea (Thecamoebians) from Eastern Canada. Cushman Foundation for Foraminiferal Research, Special Publication 21:1-63.

Medioli, F.S. and Scott, D.B. 1988. Lacustrine thecamoebians (mainly Arcellaceans) as potential tools for palaeolimnological interpretations. Paleogeography, Paleoeclimatology, Paleoecology, 62:361-386.

Medioli, F.S., Bonnet, L., Scott, D.B., and Medioli, B.E. 2003. The Thecamoebian Bibliography, 2nd edition. Palaeontologia Electronica 6.5.:107pp, 2.1MB; palaeo-electronica.org/paleo/2003_1/biblio/ issue1_03.htm.

Neville, L.A., McCarthy, F.M.G., and MacKinnon, M.D. 2010a. Seasonal, environmental and chemical impact on thecamoebian community composition in oil sands reclamation wetland in Northern Alberta. Palaeontologia Electronica, 13.2.13A:14pp.;

http://palaeo-electronica.org/2010_2/231/index.html

Neville, L.A., Christie, D.C., McCarthy, F.M G., and MacKinnon, M.D. 2010b. Biogeographic variation in Thecamoebian (Testate Amoebae) assemblages in lakes within various vegetation zones of Alberta, Canada. International Journal of Biodiversity and Conservation, 2: 215-224.

Neville, L.A., McCarthy, F.M.G., MacKinnon, M.D., Swindles, G.T. and Marlowe, P. (in press). Thecamoebians (Testate Ameobae) as proxies of ecosystem health and reclamation success in constructed wetlands in the oil sands of Alberta, Canada. Journal of Foraminiferal Research. (scheduled for issue 3).

Nusslin, O. 1884. Über einige Urthiere aus dem Herrenwieser See im badischen Schwarzwalde. Zeitschrift für wissenschaftliche Zoologie, 40(4):697-712, 717-724. 
Patterson, R.T. and Kumar, A. 2000 a. Use of Arcellacea (Thecamoebians) to Gauge Levels of Contamination and Remediation in Industrially Polluted Lakes. Environmental Micropaleontology, 15:257-278.

Patterson, R.T. and Kumar, A. 2000 b. Assessment of Arcellacean (Thecamoebian) assemblages, species and strains as contaminant indicators in James Lake, Northeastern Ontario, Canada. Journal of Foraminiferal Research, 30:310-320.

Patterson, R.T. and Kumar, A. 2002. A review of current testate rhizopod (thecamoebian) research in Canada. Palaeogeography, Palaeoclimatology, Palaeoecology, 180:225-251.

Patterson, R.T., Baker, T., and Burbridge, S.M. 1996. Arcellaceans (Thecamoebians) as proxies of arsenic and mercury contamination in northeastern Ontario lakes. Journal of Foraminiferal Research, 26(2):172183.

Patterson, R.T., Dalby, A., Kumar, A. and Henderson, L. 2002. Arcellaceans (thecamoebians) as indicators of land use change: settlement history of the Swan Lake Area, Ontario as a case study. Journal of Paleolimnology, 28:297-316.

Penard, E. 1902. Faune rhizopodique du bassin $d u$ Léman. Henry Kündig, Genua.

Porter, S.M. and Knoll, A.H. 2000. Testate amoebae in the Neoproterozoic Era:

evidence from vase-shaped microfossils in the Chuar Group, Grand Canyon. Paleobiology, 26(3):360-385

Porter, S., Meisterfeld, R. and Knoll, A. 2003. Vaseshaped microfossils from the Neoproterozoic Char Group, Grand Canyon: a classification guided by modern testate amoebae. Journal of Paleontology, 77(3):409-429.

Reinhardt, E.G., Dalby, A., Kumar, A., and Patterson, R.T. 1998. Utility of Arcellacean Morphotypic Variants as pollution indicators in mine tailing contaminated lakes near Cobalt, Ontario, Canada. Micropaleontology, 44 (2):131-148.

Riveiros, N.V., Babalola, A.O., Boudreau, R.E.A., Patterson, R.T., Roe, H.M. and Doherty, C. 2007. Modern distribution of salt marsh foraminifera and thecamoebians in the Seymore-Belize Inlet Complex, British Columbia, Canada. Marine Geology, 242:39-63.

Roe, H. and Patterson, R.T. 2006. Distribution of Thecamoebians (Testate Amoebae) in small lakes and ponds, Barbados, West Indies. Journal of Foraminiferal Research, 36(2):116-134.

Roe, H.M., Charman, D., and Gehrels, W.R. 2002, Fossil testate amoebae in coastal deposits in the UK: implications for studies of sea-level change. Journal of Quaternary Science, 17 (5-6):411-429.

Roe, H., Patterson, R.T. and Swindles, G.T. 2010. Controls on the contemporary distribution of lake thecamoebians (testate amoebae) within Greater Toronto area and their potential as water quality indicators. Journal of Paleolimnology, 43:955-975.
Saitama (1999): http://protist.i.hosei.ac.jp/pdb/images/ Sarcodina/Centropyxis/aculeata/aculeata_5b.html

Schmarda, L.C. 1871. Zoologie. II. Ausgabe. Band I. Wilhelm Braumüller, Wien.

Schönborn, W. 1989. The topophenetic analysis as a method to elucidate the phylogeny of testate amoebae (Protozoa-Testacealobosia and Testaceafilosia). Archiv für Protistenkunde, 127:223-245.

Schultze, F.E. 1877. Rhizopodenstudien. V. Archiv für mikroskopische Anatomie, 13:9-30.

Stein, S.F.N. 1859. Über die ihm aus eigener Untersuchung bekannt gewordenen Süsswasser-Rhizopoden. Abhandlungen der Koniglische Bohmischen Gesellschaft der Wissenschaften, 5(10):41-43.

Sudzuki, M. 1979. Marine interstitial testacea from Pulau Pinang, Malaysia. Annotationes zoologicae Japonenses, 52:50-53.

Swindles, G.T., Blundell, A., Roe, H.M. and Hall, V.A. 2010. A 4500-year proxy climate record from peatlands in the north of Ireland: the identification of widespread summer 'drought phases'? Quaternary Science Reviews (2009), doi:10.1016/j.quascirev.2009.01.003.

Taranek, K.J. 1881. Beiträge zur Kenntniss der Süsswasser-Rhizopoden Böhmens. Sitzungsberichte der Königlichen Böhmischen Gesellschaft der Wissenschaften?:220-235.

ter Braak, C.J.F. 2002. CANOCO for Windows version 4.51. Biometris-Plant Research International, Wageningen.

Tolonen, K., 1986. Rhizopod analysis. p. 645-666. In Berglund, B.E. (ed.), Handbook of Holocene Palaeoecology and Palaeohydrology. John Wiley and Sons, New York, NY, USA.

van Hengstum, P.J., Reinhardt, E.G., Medioli, F.S. and Gröcke, D.R. 2007. Exceptionally preserved late Albian (Cretaceous) Arcellaceans (Thecamoebians) from the Dakota Formation near Lincoln, Nebraska, USA. Journal of Foraminiferal Research, 37 (4):3003008.

van Oye, P. 1949. Rhizopodes de Java. Bijdragen tot de Dierkunde, 28:327-352.

von Siebold, C.T.E. 1845. Wirbellose Thiere: part 1, p. 1679. In von Siebold, C.T. E. and von Stannius, H. (eds.), Lehrbuch der Vergleichenden Anatomie. Veit, Berlin.

Ward, J. 1963. Hierarchical grouping to optimize an objective function. Journal of the American Statistical Association, 58:236-244.

Woodland, W.A., Charman, D.J., and Sims, P.C. 1998. Quantitative estimates of water tables and soil moisture in Holocene peatlands from testate amoebae. The Holocene, 8:261-273. 